NBER WORKING PAPER SERIES

THE EFFECT OF SUBJECTIVE SURVIVAL PROBABILITIES ON RETIREMENT
AND WEALTH IN THE UNITED STATES

\author{
David E. Bloom \\ David Canning \\ Michael Moore \\ Younghwan Song \\ Working Paper 12688 \\ http://www.nber.org/papers/w12688 \\ NATIONAL BUREAU OF ECONOMIC RESEARCH \\ 1050 Massachusetts Avenue \\ Cambridge, MA 02138 \\ November 2006
}

This paper was presented at a conference on 'Population Aging, Intergenerational Transfers, and the Macroeconomy', hosted by the Nihon University Population Research Institute, 26-28 June 2006, Tokyo. The authors are grateful to David de la Croix and to the conference organizers and participants for their thoughtful comments and suggestions. The National Institute of Aging provided support for this research (Grant No. 1 P30 AG024409-01). The views expressed herein are those of the author(s) and do not necessarily reflect the views of the National Bureau of Economic Research.

(C) 2006 by David E. Bloom, David Canning, Michael Moore, and Younghwan Song. All rights reserved. Short sections of text, not to exceed two paragraphs, may be quoted without explicit permission provided that full credit, including $(\mathcal{C}$ notice, is given to the source. 
The Effect of Subjective Survival Probabilities on Retirement and Wealth in the United States David E. Bloom, David Canning, Michael Moore, and Younghwan Song

NBER Working Paper No. 12688

November 2006

JEL No. D1,I1,J1,J22

\begin{tabular}{|c|c|}
\hline \multicolumn{2}{|c|}{ ABSTRACT } \\
\hline \multicolumn{2}{|c|}{$\begin{array}{l}\text { We explore the proposition that expected longevity affects retirement decisions and a } \\
\text { using micro data drawn from the Health and Retirement Study for the United Stat } \\
\text { a person's subjective probability of survival to age } 75 \text { as a proxy for their prospectiv } \\
\text { to control for the presence of measurement error and focal points in responses, as well a } \\
\text { we instrument subjective survival probabilities using information on current age, } \\
\text { the respondent's parents. Our estimates indicate that increased subjective probabilitie } \\
\text { in increased household wealth among couples, with no effect on the length of the } \\
\text { findings are consistent with the view that retirement decisions are driven by instit } \\
\text { and incentives and that a longer expected lifespan leads to increased wealth acc }\end{array}$} \\
\hline David E. Bloom & Michael Moore \\
\hline Harvard University & Queen's University Belfast \\
\hline Department of Population and & Room 26.G01 \\
\hline International Health & 25 University Square \\
\hline Building I, Room 1110B & Belfast, BT7 1NN IRELAND \\
\hline 677 Huntington Ave. & m.moore@qub.ac.uk \\
\hline Boston, MA 02115 & \\
\hline and NBER & Younghwan Song \\
\hline dbloom@hsph.harvard.edu & $\begin{array}{l}\text { Union College } \\
\text { Department of Economics }\end{array}$ \\
\hline David Canning & Social Sciences Building \\
\hline Harvard School of Public Health & 807 Union Street \\
\hline SPH Population International Health & Schenectady, NY 12308 \\
\hline SPH1 1211 & songy@union.edu \\
\hline 677 Huntington Avenue & \\
\hline $\begin{array}{l}\text { Boston, MA } 02115 \\
\text { dcanning@ hsph.harvard.edu }\end{array}$ & \\
\hline
\end{tabular}




\section{The Effect of Subjective Survival Probabilities on Retirement and Wealth in the United States}

David E. Bloom, David Canning, Michael Moore, and Younghwan Song

The lifecycle model of savings is among the best-established constructs in the field of economics. According to this model, people save during their prime working years to finance their consumption during retirement. Although the main predictions of this theory are well-supported empirically, pure lifecycle models are not naturally suited to explaining sharp increases in savings rates at all ages, such as those observed in East Asia between 1950 and 1990 (see Deaton 1992 for Thailand and Deaton and Paxson 1994, 1997, 2000 for Taiwan). ${ }^{2}$

Lee, Mason and Miller (1998, 2000) hypothesize that the need to finance a longer period of retirement can account for an upward shift in the age-savings profile. They simulate for Taiwan a lifecycle model with a fixed retirement age to demonstrate that rapidly improving life expectancy can account for a rise in savings at all ages and a concomitant surge in the rate of national savings. Tsai, Chu and Chung (2000) show that the timing of the rise in household savings in Taiwan coincides closely with the increases in life expectancy of the population.

Bloom, Canning and Graham (2003) construct a model of aggregate savings that includes life expectancy as an argument and estimate the parameters of the model using

\footnotetext{
${ }^{2}$ For example, the private savings rate in Taiwan rose from around 5 percent in the 1950s to well over 20 percent in the 1980s and 1990s.
} 
cross-country panel data. Their findings suggest that increases in life expectancy play a large role in savings behavior and can account for the observed savings boom in East Asia. Although such an effect is plausible given strong disincentives for the delay of retirement, Deaton and Paxson (2000) argue that in a flexible economy, without mandatory retirement, a rise in longevity will primarily affect the span of the working life, not the rate of savings. Bloom, Canning and Moore (2004) formalize this argument to show that under reasonable assumptions the optimal response to an improvement in health and a rise in life expectancy is to increase the length of working life, though less than proportionately, with no need to raise savings rates at all (due to the gains derived from compound interest over a longer life span). ${ }^{3}$ This result implies that the institutional features of retirement systems, such as mandatory retirement that prevents workers from lengthening their working lives, drive the positive effect of longevity on savings found in cross-country studies. ${ }^{4}$ To examine this issue, Bloom et al. (2007) construct a model in which retirement and savings decisions are jointly determined and in which variations in health status, expected longevity, and features of the Social Security system are allowed to influence retirement and savings behavior. Their empirical results indicate that longer

${ }^{3}$ Kalemli-Ozcan and Weil (2005) develop a model that examines the effect of declining uncertainty about age at death on the number of years spent in retirement at the end of the lifecycle. For an overlapping-generations model that highlights the effect of longevity on retirement and the accumulation of cohort-specific schooling capital, see Boucekkine, de la Croix and Licandro (2002). For a general-equilibrium overlapping-generations model that highlights the effect of longevity on both retirement and savings, see Kulish, Smith and Kent (2006).

${ }^{4}$ According to Gruber and Wise (1998) and Blondal and Scarpetta (1997), social security systems in many countries offer individuals strong financial incentives to retire at particular ages. These studies also provide evidence that workers respond by retiring earlier than they would in the absence of these incentives. 
life expectancy increases savings in countries with mandatory retirement, but has little effect on savings in countries where incentives for retirement are close to age-neutral. ${ }^{5}$

This paper examines these ideas using microdata drawn from the Health and Retirement Study (HRS) for the United States. The HRS provides data on labor supply and household wealth and a rich set of controls for a large representative sample of individuals aged 51-61 in 1992 who were followed through 2004. The HRS is ideally suited to our study because it includes information on respondents' subjective probabilities of survival. We analyze the validity of this variable as a proxy for life expectancy and use information on the current ages or the ages at death of respondents' parents as instruments to correct for the presence of classical measurement error, focal points in responses and possible reverse causality.

In the following section we describe the nature and configuration of the HRS data and summarize previous studies of the information content of key HRS variables. Next we motivate our instrumental-variables estimators by focusing on the validity of the subjective survival probabilities. Then we report and discuss our IV probit estimates of the determinants of retirement and our IV estimates of the determinants of wealth, with the subjective survival probability being the main determinant of interest. In the final section we summarize our results and discuss their policy implications.

5 There is one other potential explanation for an effect of longer life expectancy on wealth accumulation but not age at retirement: if the years of life gained are not healthy ones, age at retirement will tend to be stable and an increase in lifecycle savings will be needed to finance consumption during a longer period of 'physiologically forced' retirement. Recent evidence for the US tends to counter this explanation, supporting the Fries (1980) conjecture of a 'compression of morbidity' whereby the duration of time spent in chronic ill health toward the end of life has declined-in relative, and possibly also absolute-terms (see Fries 1989; Crimmins, Saito and Ingegneri 1997; Costa 2002; Crimmins 2004; and Mor 2005). 


\section{Data}

To investigate the effects of expected longevity on retirement and wealth, we use data drawn from the Health and Retirement Study (HRS). The HRS is a nationally representative panel survey of noninstitutionalized individuals aged 51-61 in 1992 and their spouses or partners, whose ages can fall outside this range. The first wave of the HRS consists of 12,652 individuals. The HRS collects extensive information about the retirement, health and economic well-being of the respondents. After the initial wave of interviews in 1992, subsequent waves of interviews were fielded biennially. We use the RAND HRS data file, which is a cleaned and streamlined version of the HRS that includes some additional derived variables.

As a proxy for expected longevity, we use the subjective survival probability available in the HRS. ${ }^{6}$ In the first wave of interviews in 1992, 12 questions in the HRS asked for subjective probabilities about future events. They include the following two questions about surviving to the target ages of 75 and 85: 'Using any number from zero to ten where 0 equals absolutely no chance and 10 equals absolutely certain, what do you think are the chances you will live to be 75 or more?' '85 or more?' ${ }^{7}$ At the aggregate

${ }^{6}$ In an early economic study of the information content of subjective survival probabilities, Hamermesh (1985) reports evidence that individuals' subjective survival probabilities are reasonably consistent with actuarial evidence on those probabilities and strongly correlated with the longevity of their parents and grandparents. Hamermesh derives evidence from two survey data sets: one consisting of 411 male economists ranging in age from 26 to 65, and the other consisting of 363 males between ages 20 and 70 who resided in a medium-sized standard metropolitan statistical area in the Midwestern part of the US. In another analysis of the same data sets, Hamermesh and Hamermesh (1983) report that subjective survival probabilities are reflective of individual-specific information on smoking and obesity, but not exercise.

${ }^{7}$ The other questions involving subjective probabilities were as follows: 'What do you think are the chances that housing prices in your neighborhood will go up faster than prices in general over the next 10 years?', 'What do you think are the chances that the U.S. economy will experience a major depression sometime during the next 10 years or so?', 'What do you think are the chances 
level, the answers to these questions about subjective survival probabilities have been found to measure mortality risk fairly reasonably: they aggregate well to averages that are close to corresponding figures based on age-specific survival probabilities calculated from cross-sectional life tables, and they vary plausibly with income, wealth, schooling, and risk factors such as smoking (Hurd and McGarry 1995). In panel analysis the subjective survival probabilities to age 75 at wave 1 , independent of self-assessed health status, are reasonably predictive of actual mortality during the two years between waves 1 and 2 (Hurd and McGarry 2002). If one controls for self-assessed health status, however, subjective survival probabilities to age 75 from the HRS are poor predictors of mortality during the three years after wave 1 (Siegel, Bradley and Kasl 2003).

At the individual level the quality of subjective survival probabilities as predictors of respondents' life expectancy seems to suffer from the presence of classical measurement error and focal points in responses (Hurd and McGarry 1995; Hurd, McFadden and Gan 1998; Bassett and Lumsdaine 2001). Hurd and McGarry (1995) present clear evidence of response error by showing that 2.5 percent of the respondents reported larger values for the survival probability to age 85 than for the survival probability to age 75 . Hurd, McFadden and Gan (1998) show that due to cognition and response error many respondents systematically provided focal-point answers $(0,0.5$ or

that the U.S. economy will experience double-digit inflation sometime during the next 10 years or so?', 'What do you think are the chances that you [or your (husband/wife/partner)] will have to give major financial help to family members during the next 10 years?', 'Thinking about work generally and not just your present job, what do you think are the chances that you will be working full-time after your reach age 62?', 'And what about the chances that you will be working full-time after you reach age 65?', 'How likely is it that you will lose your job during the next year?', 'What about the chances that your health will limit your work activity during the next 10 years?', 'And what are the chances that Congress will change the Social Security law to make the system more generous than it is now?', and 'How about the chances that Congress will change Social Security so that it becomes less generous than now?' 
1) to the questions on subjective survival probabilities in the sample of older individuals (aged 70 and over in 1993) in the Study of Assets and Health Dynamics among the Oldest Old (AHEAD). Unlike the younger generation of respondents in the HRS, however, the older respondents in the AHEAD study reported average subjective survival probabilities that were substantially higher than those from life tables. Thus the problem of focal points in responses may be a less severe one in the HRS than in the AHEAD study. Bassett and Lumsdaine (2001) demonstrate the possibility of systematic response error, showing that respondents who gave probabilistically inconsistent answers to the two questions regarding Social Security in the HRS also reported higher values for subjective survival probabilities. ${ }^{8}$

To improve the information content of responses to the subjective survival probabilities in the AHEAD study, Hurd, McFadden and Gan (1998) transform the errorridden survival probabilities with focal points into continuous probabilities. They show that savings is positively associated with their new survival probabilities among couples, though not among singles. ${ }^{9}$ But they do not validate their new survival probabilities—-for instance, by using actual mortality information from panel data. Bassett and Lumsdaine (2001) try to validate their measures for other subjective probabilities in the HRS. Their analysis of patterns in the minimum, maximum, mean and range of the entire set of

\footnotetext{
${ }^{8}$ According to Bassett and Lumsdaine (2001) the sum of the probabilities given for each of the two questions about Social Security-Congress will change the Social Security law to make the system more generous or less generous? - should be less than or equal to 100; but they report that 1492 respondents (about 18 percent of their sample) gave answers that summed to more than 100 . The initial assumption is problematic, however, as there is no reason to think that Social Security benefits could not become more generous at some point in the future and less generous at some other point.

${ }^{9}$ Hurd, McFadden, and Gan (1998) used a simple ordered probit analysis in which the dependent variable was the categorical information on whether each respondent was a net saver, a zero saver, or a net dissaver.
} 
responses to the subjective probability questions in the first wave of the HRS suggests the presence of unobserved individual heterogeneity. To adjust for this individual fixed effect, they create five benchmark measures by renormalizing the location or scale of reported subjective probabilities. The result is inconclusive. In predicting the actual outcomes observed by the third wave of the HRS, their benchmark measures for the subjective probability of working full-time past age 62 and for the subjective probability of making a gift to family members perform poorly relative to the reported responses.

We control for these measurement errors in the HRS by instrumenting the subjective survival probabilities of respondents using information on the mortality experience of their parents. The instrumental-variables estimator also addresses the potential endogeneity of subjective survival probabilities, a problem that would arise if the subjective survival probabilities were affected by wealth and retirement decisions.

Hurd and McGarry (1995) show that parents' ages or ages at death are substantially correlated with the subjective survival probabilities of respondents, and the relationships between parents' ages at death and the subjective survival probabilities are nonmonotonic: the subjective survival probabilities of respondents are higher if the parents are alive than if the parents have died; but if the parents died before age 51 , the subjective survival probabilities of respondents are higher than if the parents died between ages 51 and 65, presumably because accidental deaths are more likely among deaths that occur at younger ages; and if the parents died at an age greater than 65 , the subjective survival probabilities of respondents increase with the parents' ages at death. ${ }^{10}$

\footnotetext{
${ }^{10}$ Hurd, McFadden and Gan (1998) also use the parental mortality experience to correct for errors in subjective survival probabilities in their sample from the AHEAD study. They too find that greater parental longevity is in general associated with greater subjective probability of survival,
} 
In their analysis of HRS panel data, Hurd and McGarry (2002) report that respondents modify their subjective survival probabilities in response to the death of a parent.

\section{Validation}

Using the sample of respondents whose actual mortality is known by wave 6 of the HRS, completed in 2002 , we test how well the instrumented survival probability to age 75 predicts actual mortality in the subsequent waves, relative to the reported survival probability from the first wave. Our validation process is similar to that in Hurd and McGarry (2002). Details of the validation results are reported in the Appendix. We find that the instrumented survival probability, which corrects for measurement error, performs substantially better than the reported survival probability as a predictor of longterm mortality. In the next two sections we employ this instrumented subjective survival probability to investigate the effects of subjective survival probabilities on retirement and wealth.

\section{Empirical results}

In this section we estimate the effect of subjective survival probabilities on wealth accumulation and retirement. We find that higher subjective survival probabilities lead to greater household wealth among couples, but not among singles, and no significant differences in the probability of retirement for individuals in either demographic group.

but the relationship is statistically significant only for females when the father's longevity is higher. In addition to the differences in data, two other differences make the results by Hurd, McFadden and Gan (1998) not directly comparable to those by Hurd and McGarry (1995). First, according to Hurd and McGarry (1995), the effects of parental longevity on the subjective survival probability of the respondents are not linear. Hurd, McFadden and Gan (1998) employed a linear specification. Second, Hurd and McGarry (1995) create dummy indicators for surviving parents, whereas Hurd, McFadden and Gan (1998) use the expected age at death conditional on the age attained, calculated from life tables. 


\section{Retirement analysis}

Using the summary labor force status variable in the RAND HRS data, we define individuals as in the labor force if they are working full-time, working part-time, or are unemployed. Respondents who are not in the labor force-retired, partially retired, disabled, or not in the labor force in the summary labor force status variable—are defined as retired in our analysis. ${ }^{11}$

The sample we use in our cross-sectional analysis of retirement consists of individuals aged 50-70 in 1992 who were not represented by a proxy respondent. We exclude those with missing data on subjective survival probabilities and on parental mortality ( 3 percent of the initial sample). Our sample includes respondents outside the 51-61 age range because we include spouses of the age-eligible respondents. Of the 9388 observations in the final sample used for our cross-sectional analyses, 8235 (88 percent) were born between 1931 and 1941 and 1153 (12 percent) were born either before 1931 or after 1941. We present the results using the subjective survival probabilities to age 75 as our measure of subjective survival probabilities. ${ }^{12}$

Figure 1 reports the retirement rate by age for the whole sample. The proportion of respondents retired rises with age, with sharp jumps between 61 and 62 and again

\footnotetext{
${ }^{11}$ The summary labor force status variable in the RAND HRS data is based on the following information: working for pay, employment status, retired, looking for work, usual hours worked per week, usual weeks worked per year, and information on second job. Hurd, Smith and Zissimopoulos (2004) use the same definition of retirement. According to Gustman and Steinmeier (2000), there are alternative definitions of retirement in the HRS. We plan to conduct further analyses based on these alternative definitions of retirement.

${ }^{12}$ The results do not substantially change when the subjective survival probabilities to age 85 are used instead.
} 
between 64 and 65 . These jumps correspond to the ages of eligibility for rising levels of Social Security benefits. ${ }^{13}$

We conduct separate analyses by household living arrangements (i.e. single or couple) and by sex. In addition to the subjective survival probability to age 75 and a standard set of demographic variables - age, three race/ethnicity dummies (the reference group is white), years of education, and number of children-we also generate, as regressors, five dummy variables based on the financial planning horizon (the reference group is the planning horizon of a few months), ${ }^{14}$ four dummy variables for self-reported health status (the reference group is 'poor health'), a dummy variable for the presence of a health problem that limits the kind or amount of paid work of the respondent, and the amount of lump-sum payments received from inheritance, insurance, and pension during 1991. ${ }^{15}$ For couples our specification includes these explanatory variables as well as the survival probability for each spouse in order to control for joint decision-making. Accordingly our instrumental-variables estimates instrument the survival probabilities of both spouses with the parental mortality experience of both spouses.

Table 1 reports the results of the retirement probit and the IV retirement probit for singles. ${ }^{16}$ Among singles, there is no evidence that higher subjective survival

\footnotetext{
${ }^{13}$ The drop in the retirement rate observed after age 68 seems to be due to small sample sizes. The numbers of observations for ages 69 and 70 are 36 and 22 respectively. Moreover, t-tests confirm that the retirement rates are not significantly different between ages 68 and 69 or between ages 69 and 70 .

${ }^{14}$ Respondents were asked about the time period that was important when planning their savings and spending. The results do not substantially change when dummy variables for planning horizon are excluded.

${ }^{15}$ The amount of inheritance is not separately available in the RAND HRS files.

${ }^{16}$ In the first-stage IV estimation of the retirement and wealth equations, the coefficients on the dummy variables for the mortality experience of the parents, though unreported, show the same signs and significance as those reported in Table A4.
} 
probabilities decrease the probability of retirement, regardless of sex and estimation method. Other significant variables are consistent with the findings in the literature. Older individuals are more likely to have retired in our sample. ${ }^{17}$ More-educated women are less likely to have retired than less-educated women. Those in poor health and having health problems are more likely to have retired than those in better health with no health problems. Women with the longest planning horizon are more likely to have retired than those with the shortest planning horizon (a few months).

The conclusions from Table 1 on the effect of subjective survival probabilities on retirement behavior do not change in Table 2, where we report probit and IV probit results for couples. The coefficients on the subjective survival probabilities are statistically insignificant for both spouses, except for males in column 1, which is significant at the 10 percent level. The coefficients on the age-dummy variables among men clearly demonstrate sharp jumps at ages 62 and 65. Having an older spouse increases the likelihood of retirement, as does receiving more lump-sum income in 1991.

Overall, there is no evidence that higher subjective survival probabilities decrease the probability of retirement regardless of couple status, sex, control variables, and estimation method.

\section{Wealth analysis}

We define wealth as the sum of all household wealth components less all debt, exclusive of Social Security and pension wealth. We use imputed values in the RAND HRS when any of the wealth components is missing. The unit of analysis is the household because wealth is measured at the household level. We conduct separate analyses by couple

\footnotetext{
${ }^{17}$ The reference group is age 50 .
} 
status. Figure 2 presents the distribution of wealth by couple status. Because some households have zero or negative wealth, we do not use a logarithmic specification. The mean wealth and median wealth for singles are \$95 711 and \$27 990 respectively, and the mean wealth and median wealth for couples are \$239 109 and \$118 500 respectively.

Table 3 reports the results of the OLS and IV estimation of the wealth equation for singles. We use the same set of explanatory variables as we use in the retirement equations. ${ }^{18}$ Among singles there is no evidence that higher subjective survival probabilities increase the wealth of the respondent, regardless of estimation method. The result of the Durbin-Wu-Hausman test cannot reject the null hypothesis that the OLS estimate in column 1 of Table 3 is consistent. Other explanatory variables in Table 3 show expected signs. Women have less wealth than men. Blacks have less wealth than whites. Consistent with the literature, better-educated people have more wealth than lesseducated people. Individuals with planning horizons of longer than five years have more wealth than those with shorter planning horizons.

Table 4 reports the results of the OLS and IV estimation of the parameters of the wealth equation for couples. Column 2 of Table 4 shows that among couples, higher subjective survival probabilities of both spouses significantly increase the wealth of the household in the IV estimation. The coefficients on the subjective survival probabilities in column 2 of Table 4 indicate that a 10 percentage point increase in the husband's subjective survival probability results in roughly a \$27 600 increase in household wealth, while a 10 percentage point increase in the wife's subjective survival probability results

${ }^{18}$ Instead of the age dummy variables, we have included age and its square in the wealth equation. 
in roughly a $\$ 32700$ increase in household wealth. These amounts are more than 10 percent of the mean household wealth for couples.

Table 4 also reports the results of three tests for the validity of our approach. The Durbin-Wu-Hausman test indicates that the OLS estimates are inconsistent. The p-value from the Sargan test of overidentification indicates that our instruments are uncorrelated with the error term and also that they are correctly excluded from the wealth equation. Finally the Craig-Donald statistic shows that one cannot regard the instruments as weak. $^{19}$

Overall, the difference in the effect of subjective survival probabilities by couple status reported in Tables 3 and 4 is consistent with the findings of Hurd, McFadden, and Gan (1998).

\section{Summary and conclusion}

We find that increased subjective probabilities of survival result in increased household wealth among couples, with no effect on the length of the working life. This finding is consistent with the view that a longer expected lifespan leads to increased wealth accumulation because institutional incentives effectively constrain retirement decisions. We intend to exploit the panel nature of the HRS in future work by extending the analysis forward through the seventh wave (2004). We also intend to explore the use of answers to other questions on subjective probabilities as instruments for the subjective survival probabilities, and to study lifetime savings directly by analyzing HRS data that are linked

\footnotetext{
${ }^{19}$ Critical values for the Craig-Donald statistic for the presence of weak instruments based on two-stage least squares bias are 20.69, 11.05, 6.06 and 4.32 for the 5 percent, 10 percent, 20 percent and 30 percent bias respectively. If the Crag-Donald statistic is less than the critical value, the instruments are weak. See Stock and Yogo (2002) for details.
} 
to individual records on lifetime Social Security earnings. Future analyses will also encompass individual data from the English Longitudinal Study of Ageing (ELSA) and the Survey of Health, Ageing and Retirement in Europe (SHARE), so that we can test more directly whether institutions influence retirement incentives (see Bloom, Canning, Moore and Song 2006).

Our results indicate that expected lifetime horizons influence economic decisions of consequence. This suggests that improving the accuracy of people's estimates of those horizons, and of the state of their health during those years, could enhance their lifetime welfare. Further research, along the lines of Bongaarts and Feeney (2003), that aims to extract information about the survival probabilities of true cohorts from data on the survival probabilities of synthetic cohorts-on which life expectancy estimates are typically formed—would be quite worthwhile.

Our results also suggest that eliminating institutional arrangements that impinge on retirement behavior, or making those arrangements responsive to changes in life expectancy, could lead to welfare-enhancing changes in labor supply and savings. The Social Security system in the United States has started down this path by increasing the age at full retirement from 65 for cohorts born before 1937 to 67 for cohorts born after 1960. These changes coincide closely with the 1980-2003 increase in life expectancy at age 65 from 16.4 to 18.4 years. In view of the projection of $\mathrm{Li}$ and Lee (2005) that life expectancy at birth in the United States will rise to 84.9 by 2050 (from 77.5 in 2003), further increases in the Social Security retirement age may well be in the offing. 


\section{Appendix}

Our validation sample consists of 10070 individuals who were 45-65 in 1992, who were not represented by a proxy interview at wave 1 , and whose mortality status by wave 6 is known. ${ }^{20}$ We exclude those with missing data on subjective survival probabilities and the mortality of parents. The cumulative mortality rate among this sample of 10070 individuals is reported by each wave in Table A1. By wave 6 (2002), almost 12 percent of the sample had died. ${ }^{21}$ For each and every wave, men show significantly higher cumulative mortality rates than women.

Figure A1 reports the histogram of the distribution of the reported subjective survival probability to age 75 that has been normalized to $[0,1]$ from $[0,10]$. The figure clearly illustrates that there are substantial focal-point responses, regardless of sex: more than 40 percent of the respondents answered that their survival probability to age 75 is either 0.5 or 1 . The fact that respondents had to choose a number between 0 and 10 may have aggravated the problem of focal-point responses.

Table A2 shows how well this subjective survival probability at wave 1 predicts actual mortality between wave 1 and each subsequent wave by way of probit estimation. The dependent variable is equal to 1 if the individual has died by wave $t(t=2,3,4,5$, and 6) and 0 if he or she has survived. Overall the reported marginal effects of the survival probability to age 75 in Table A2 show that higher values of subjective survival

\footnotetext{
${ }^{20}$ Outside the age range 51-61, the sample is not representative of the population in 1992 . Yet our analysis includes those respondents outside the age range 51-61 who are spouses or partners of age-eligible individuals to have more age variation and more observed deaths than in the ageeligible sample.

${ }^{21}$ The individuals who we exclude because of missing data on subjective survival probabilities and the mortality of parents (502 observations) have significantly higher cumulative mortality rates than those included in the sample. By wave 6, for instance, about 17 percent of the individuals in this excluded group had died.
} 
probability to age 75 at wave 1 significantly reduce the probability of dying before subsequent waves. When the question regarding the subjective survival probability to age 75 was asked of respondents who were 45-65 years old in 1992, it was intended to measure the long-term mortality (or survival) probability over the next 10 to 30 years. The fact that the marginal effects of the subjective survival probability to age 75 at wave 1 are both significant and increasing in magnitude over time in Table A2 provides some evidence that the subjective survival probability to age 75 at wave 1 does indeed predict people's long-term mortality.

However, it is possible that the marginal effects of the subjective survival probability in Table A2 reflect the effects of other factors that would affect mortality, such as age, sex, education, health status, disease conditions, smoking behavior, income and wealth, because these factors have not been controlled for in Table A2. ${ }^{22}$ We include these factors from wave 1 in Table A3 as explanatory variables in addition to the subjective survival probability to age $75 .^{23}$

Consistent with the findings of Hurd and McGarry (2002), higher values of subjective survival probability to age 75 significantly reduce the probability of dying by wave 2, as shown in column 1 of Table A3. Significant coefficients on other explanatory variables have the expected signs. Mortality increases with age. Women have lower mortality rates than men. The four dummy variables for subjective health status (poor health is the reference group) are significant with the expected signs. Disease conditions increase mortality rates. Current and past smoking increases mortality rates.

\footnotetext{
${ }^{22}$ Our income and wealth measures refer to wave 1 and can therefore be regarded as exogenous in the estimation of mortality in subsequent waves.

${ }^{23}$ Hurd and McGarry (2002) use almost the same explanatory variables.
} 
Yet columns 2 through 5 of Table A3 reveal that when it comes to predicting long-term mortality by waves 3 through 6 , the reported survival probability does not provide additional explanatory power after other risk factors are controlled. The marginal effects of the reported survival probability are insignificant and the magnitude does not increase over time, though the sign is correct. Such an outcome is possible given that the reported subjective survival probability is subject to measurement error.

To correct for measurement error, we instrument the reported subjective survival probability to age 75 by using 12 dummy variables for the mortality experience of the parents. Table A4 reports the results of the first-stage linear-probability estimation to predict the subjected survival probability to age 75 in the mortality equation. The table includes other exogenous variables from the main mortality equation, and they show reasonable signs. For the 12 dummy variables for the mortality experience of the parents, the reference group consists of those respondents whose parents died between the ages of 50 and 65. In the first stage of the IV estimation, the coefficients on these instrumental variables are significant with the expected signs and magnitudes, even after we control for smoking behavior and disease conditions. If the parents are alive, the subjective survival probability to age 75 of the respondent is greater by $0.051 \sim 0.095$ in comparison with those whose parents died between the ages of 50 and 65 . The effect of the parents' age at death on the subjective survival probabilities is nonmonotonic: if the parents died before age 50, the subjective survival probability to age 75 of the respondent increases by 0.037 0.040; if the parents died between the ages of 66 and 75, the subjective survival probability to age 75 increases by $0.023 \sim 0.027$; and if the parents died after age 75 , the subjective survival probability to age 75 increases even more. 
Figure A2 reports the histogram and kernel density graph of the instrumented subjective survival probability based on the results reported in table A4. In comparison with the histograms of the reported survival probability in Figure A1, the distribution of the instrumented subjective survival probability in Figure A2 is unimodal and continuous, and it falls well within 0 and $1 .{ }^{24}$ In the full sample the correlation coefficient between the reported survival probability and the instrumented survival probability is 0.4297 and statistically significant at the 1 percent level.

Tables A5 and A6 report the marginal effects of the instrumented subjective survival probability from probit estimation of the mortality equation for each wave. Similar to the results in Table A2, the magnitude of the marginal effects of the instrumented subjective survival probability on actual mortality increases over time in Table A5, where no control variables have been included other than the instrumented subjective survival probability. Furthermore, one notices that when the same columns from the two tables are compared, the magnitudes of the marginal effects are substantially larger in Table A5 than in Table A2, especially in columns 3, 4 and 5. This indicates that the instrumented subjective survival probability is a better predictor of long-term mortality than the reported subjective survival probability.

This conclusion does not change in Table A6, where other control variables are included. In predicting long-term mortality between waves 3 through 6 , the marginal effect of the instrumented survival probability becomes gradually larger in absolute

\footnotetext{
${ }^{24}$ The minimum and maximum values for the instrumented subjective survival probability are 0.14 and 0.93 respectively.
} 
magnitude, except for wave 3 , and significant in predicting long-term mortality by wave $6 .^{25}$

${ }^{25}$ Those who were 45-65 years old in wave 1 were $55-75$ years old in wave 6 . 
Table 1. Retirement probit estimation, singles

\begin{tabular}{|c|c|c|c|c|}
\hline \multirow[b]{3}{*}{ Predictor variable } & \multicolumn{2}{|r|}{ Men } & \multicolumn{2}{|c|}{ Women } \\
\hline & (1) & (2) & (3) & (4) \\
\hline & Probit & IV Probit & Probit & IV Probit \\
\hline SURVIVAL PROBABILITY TO 75 & $.100(.214)$ & $1.239(1.405)$ & $-.021(.141)$ & $.572(.849)$ \\
\hline Age 51 & $.816^{*}(.440)$ & $.830^{*}(.450)$ & $.218(.254)$ & $.261(.264)$ \\
\hline Age 52 & $.558(.436)$ & $.624(.455)$ & $.017(.262)$ & $.057(.272)$ \\
\hline Age 53 & $.519(.435)$ & $.572(.449)$ & $.091(.262)$ & $.125(.269)$ \\
\hline Age 54 & $.571(.448)$ & $.521(.463)$ & $.098(.256)$ & $.146(.268)$ \\
\hline Age 55 & $.286(.458)$ & $.337(.470)$ & $-.030(.268)$ & $-.017(.271)$ \\
\hline Age 56 & $.589(.448)$ & $.579(.458)$ & $.302(.252)$ & $.356(.267)$ \\
\hline Age 57 & $.708(.436)$ & $.694(.446)$ & $.195(.255)$ & $.231(.261)$ \\
\hline Age 58 & $1.263^{\star *}(.441)$ & $1.231^{\star *}(.450)$ & $.235(.254)$ & $.295(.272)$ \\
\hline Age 59 & $.995^{\star \star}(.439)$ & $.942^{\star \star}(.452)$ & $.525^{\star \star}(.252)$ & $.551^{* *}(.258)$ \\
\hline Age 60 & $.762^{*}(.445)$ & $.710(.459)$ & $.795^{\star \star}(.247)$ & $.836^{* \star}(.259)$ \\
\hline Age 61 & $1.399^{* *}(.457)$ & $1.476^{* *}(.483)$ & $.871^{\star \star}(.259)$ & $.895^{\star \star}(.265)$ \\
\hline Age 70 & & & $.822(.1 .217)$ & $.817(.1 .137)$ \\
\hline Black & $.312^{\star \star}(.150)$ & $.145(.245)$ & $.283^{\star \star}(.094)$ & $.250^{* *}(.105)$ \\
\hline Hispanic & $.398^{*}(.238)$ & $.347(.253)$ & $.240^{*}(.142)$ & $.276^{*}(.154)$ \\
\hline Other & $.195(.593)$ & $.096(.636)$ & $.474^{\star}(.254)$ & $.490^{*}(.260)$ \\
\hline Years of education & $.026(.021)$ & $.022(.022)$ & $-.060^{* *}(.015)$ & $-.064^{\star *}(.016)$ \\
\hline \multicolumn{5}{|l|}{ HEALTH } \\
\hline Excellent & $-1.057^{\star \star}(.300)$ & $-1.552^{\star *}(.710)$ & $-.851^{\star *}(.191)$ & $-1.049^{\star *}(.345)$ \\
\hline Very good & $-.838^{* \star}(.273)$ & $-1.219^{* *}(.568)$ & $-.613^{* *}(.171)$ & $-.752^{\star \star}(.265)$ \\
\hline Good & $-.858^{* *}(.252)$ & $-1.170^{\star \star}(.492)$ & $-.778^{* *}(.160)$ & $-.889^{\star \star}(.229)$ \\
\hline Fair & $-.445^{\star}(.240)$ & $-.605^{\star}(.334)$ & $-.519^{* *}(.150)$ & $-.572^{\star \star}(.170)$ \\
\hline Health limits work & $1.618^{* *}(.163)$ & $1.538^{\star \star}(.179)$ & $1.452^{\star \star}(.108)$ & $1.457^{\star \star}(.111)$ \\
\hline \multicolumn{5}{|l|}{ PLANNING HORIZON } \\
\hline Next year & $.162(.226)$ & $.200(.242)$ & $.003(.151)$ & $-.0003(.152)$ \\
\hline Next few years & $.024(.180)$ & $-.019(.196)$ & $-.202^{*}(.108)$ & $-.198^{*}(.109)$ \\
\hline Next $5-10$ years & $.049(.186)$ & $-.010(.206)$ & $-.226^{\star}(.121)$ & $-.247^{\star}(.127)$ \\
\hline Longer than 10 years & $.235(.261)$ & $.091(.331)$ & $.427^{\star \star}(.160)$ & $.398^{\star \star}(.166)$ \\
\hline Planning horizon missing & $.340(.335)$ & $.361(.346)$ & $.210(.240)$ & $.215(.245)$ \\
\hline \multicolumn{5}{|l|}{ HOUSEHOLD } \\
\hline \multicolumn{5}{|l|}{ CHARACTERISTICS } \\
\hline Number of children & $-.021(.029)$ & $-.027(.032)$ & $.019(.019)$ & $.013(.021)$ \\
\hline $\begin{array}{l}\text { Lump sum income (in } \\
\qquad \$ 1000 \text { s) }\end{array}$ & $.005(.005)$ & $.004(.006)$ & $.008^{\star \star}(.002)$ & $.008^{\star \star}(.002)$ \\
\hline
\end{tabular}




\begin{tabular}{lccccc}
\hline & Men & & & Women \\
Predictor variable & Probit & & IV Probit & (3) & (4) \\
\hline $\begin{array}{l}\text { P-value of Wald test of } \\
\text { exogeneity }\end{array}$ & & .4374 & & IV Probit \\
$\begin{array}{l}\text { Proportion retired } \\
\text { No. of observations }\end{array}$ & .326 & .4862 \\
\hline
\end{tabular}

Notes: Standard errors in parentheses. Three observations in the male equation and one observation in the female equation are dropped because age dummies perfectly predict outcomes.

${ }^{*}$ Statistically significant at the .10 level. ${ }^{* *}$ Statistically significant at the .05 level. 
Table 2. Retirement probit estimation, couples

\begin{tabular}{|c|c|c|c|c|}
\hline \multirow[b]{3}{*}{ Predictor variable } & \multicolumn{2}{|c|}{ Men } & \multicolumn{2}{|c|}{$\underline{\text { Women }}$} \\
\hline & (1) & (2) & (3) & (4) \\
\hline & Probit & IV Probit & Probit & IV Probit \\
\hline Self survival probability to 75 & $-.176^{\star}(.094)$ & $-.431(.537)$ & $.111(.095)$ & $-.598(.437)$ \\
\hline Spouse survival probability to 75 & $.035(.100)$ & $-.393(.464)$ & $.058(.090)$ & $-.309(.516)$ \\
\hline \multicolumn{5}{|l|}{ SELF CHARACTERISTICS } \\
\hline Age 51 & $-.009(.216)$ & $-.006(.219)$ & $.151(.116)$ & $.150(.119)$ \\
\hline Age 52 & $.215(.214)$ & $.193(.214)$ & $.135(.118)$ & $.134(.121)$ \\
\hline Age 53 & $.053(.217)$ & $.040(.221)$ & $-.123(.122)$ & $-.118(.124)$ \\
\hline Age 54 & $.438^{\star \star}(.212)$ & $.414^{*}(.216)$ & $-.037(.120)$ & $-.033(.122)$ \\
\hline Age 55 & $.479^{\star \star}(.208)$ & $.460^{\star *}(.212)$ & $-.017(.119)$ & $-.025(.122)$ \\
\hline Age 56 & $.493^{\star \star}(.208)$ & $.459^{* \star}(.213)$ & $.196(.122)$ & $.189(.124)$ \\
\hline Age 57 & $.485^{\star \star}(.208)$ & $.468^{\star \star}(.213)$ & $.178(.126)$ & $.165(.129)$ \\
\hline Age 58 & $.491^{* *}(.212)$ & $.464^{* \star}(.216)$ & $.209(.127)$ & $.246^{*}(.131)$ \\
\hline Age 59 & $.705^{\star \star}(.210)$ & $.647^{\star \star}(.218)$ & $.266^{\star \star}(.128)$ & $.258^{\star *}(.131)$ \\
\hline Age 60 & $.769^{\star \star}(.208)$ & $.708^{* *}(.217)$ & $.334^{* \star}(.131)$ & $.324^{\star \star}(.135)$ \\
\hline Age 61 & $.962^{* \star}(.212)$ & $.921^{\star \star}(.217)$ & $.513^{\star \star}(.139)$ & $.499^{\star \star}(.142)$ \\
\hline Age 62 & $1.571^{\star \star}(.217)$ & $1.487^{\star \star}(.226)$ & $.909^{* *}(.265)$ & $.991^{* *}(.277)$ \\
\hline Age 63 & $1.493^{\star *}(.225)$ & $1.418^{* *}(.234)$ & $1.575^{\star \star}(.411)$ & $1.614^{\star \star}(.409)$ \\
\hline Age 64 & $1.464^{\star \star}(.230)$ & $1.410^{* *}(.238)$ & $1.066^{\star \star}(.368)$ & $1.140^{\star \star}(.378)$ \\
\hline Age 65 & $2.374^{\star *}(.256)$ & $2.275^{\star \star}(.271)$ & $.961^{\star *}(.399)$ & $.965^{* \star}(.402)$ \\
\hline Age 66 & $1.907^{\star \star}(.259)$ & $1.784^{\star \star}(.279)$ & $\mathrm{a}$ & a \\
\hline Age 67 & $2.626^{\star \star}(.303)$ & $2.556^{* *}(.313)$ & $.434(.565)$ & $.679(.591)$ \\
\hline Age 68 & $2.431^{\star *}(.334)$ & $2.329^{* *}(.347)$ & $\mathrm{a}$ & $\mathrm{a}$ \\
\hline Age 69 & $1.923^{* *}(.340)$ & $1.812^{* *}(.352)$ & $.635(.909)$ & $.701(.932)$ \\
\hline Age 70 & $1.819^{* \star}(.377)$ & $1.721^{\star *}(.392)$ & $a$ & $\mathrm{a}$ \\
\hline Black & $.151(.255)$ & $.122(.260)$ & $-.109(.283)$ & $-.080(.289)$ \\
\hline Hispanic & $-.056(.201)$ & $-.071(.204)$ & $-.158(.209)$ & $-.182(.215)$ \\
\hline Other & $-.416^{*}(.245)$ & $-.427^{*}(.248)$ & $-.115(.224)$ & $-.144(.228)$ \\
\hline Years of education & $.008(.010)$ & $.007(.010)$ & $-.076^{\star \star}(.012)$ & $-.069^{\star \star}(.013)$ \\
\hline \multicolumn{5}{|l|}{ HEALTH } \\
\hline Excellent & $-.655^{\star \star}(.129)$ & $-.837^{\star \star}(.227)$ & $-.635^{\star \star}(.150)$ & $-.382^{*}(.214)$ \\
\hline Very good & $-.735^{\star \star}(.123)$ & $-.874^{\star \star}(.193)$ & $-.639^{\star \star}(.145)$ & $-.435^{\star \star}(.191)$ \\
\hline Good & $-.697^{\star *}(.115)$ & $-.798^{\star \star}(.162)$ & $-.561^{* *}(.141)$ & $-.403^{\star \star}(.171)$ \\
\hline Fair & $-.646^{\star \star}(.117)$ & $-.680^{\star *}(.130)$ & $-.322^{\star \star}(.144)$ & $-.217(.159)$ \\
\hline Health limits work & $1.184^{* *}(.070)$ & $1.214^{* *}(.075)$ & $.753^{\star \star}(.072)$ & $.746^{\star \star}(.074)$ \\
\hline \multicolumn{5}{|l|}{ PLANNING HORIZON } \\
\hline Next year & $-.132(.101)$ & $-.125(.103)$ & $-.177^{\star}(.083)$ & $-.198^{\star *}(.095)$ \\
\hline
\end{tabular}




\begin{tabular}{|c|c|c|c|c|}
\hline \multirow[b]{3}{*}{ Predictor variable } & \multicolumn{2}{|r|}{$\underline{\text { Men }}$} & \multicolumn{2}{|c|}{$\underline{\text { Women }}$} \\
\hline & (1) & (2) & (3) & (4) \\
\hline & Probit & IV Probit & Probit & IV Probit \\
\hline Next few years & $-.226^{\star \star}(.079)$ & $-.223^{\star \star}(.080)$ & $-.261^{\star \star}(.073)$ & $-.273^{\star \star}(.075)$ \\
\hline Next $5-10$ years & $-.172^{* *}(.082)$ & $-.174^{\star *}(.083)$ & $-.244^{* *}(.078)$ & $-.238^{* *}(.080)$ \\
\hline Longer than 10 years & $.118(.104)$ & $.077(.117)$ & $.086(.105)$ & $.106(.109)$ \\
\hline Planning horizon missing & $-.033(.187)$ & $-.021(.191)$ & $.241(.205)$ & $.159(.213)$ \\
\hline \multicolumn{5}{|l|}{ SPOUSE CHARACTERISTICS } \\
\hline Age & $.013^{\star *}(.005)$ & $.015^{\star \star}(.006)$ & $.018^{* \star}(.005)$ & $.021^{* *}(.008)$ \\
\hline Black & $.070(.261)$ & $.063(.265)$ & $.147(.282)$ & $-.111(.288)$ \\
\hline Hispanic & $-.071(.189)$ & $-.110(.194)$ & $-.013(.203)$ & $.014(.208)$ \\
\hline Other & $.177(.199)$ & $.187(.201)$ & $.274(.200)$ & $-.213(.206)$ \\
\hline Years of education & $-.000(.012)$ & $-.002(.013)$ & $-.010(.009)$ & $.012(.010)$ \\
\hline \multicolumn{5}{|l|}{ SPOUSE HEALTH } \\
\hline Excellent & $-.126(.149)$ & $.018(.217)$ & $-.087(.129)$ & $.091(.230)$ \\
\hline Very good & $-.092(.142)$ & $.038(.191)$ & $-.055(.123)$ & $.096(.196)$ \\
\hline Good & $-.134(.137)$ & $-.039(.172)$ & $-.133(.117)$ & $-.007(.167)$ \\
\hline Fair & $-.026(.138)$ & $.039(.153)$ & $-.148(.118)$ & $-.071(.134)$ \\
\hline Health limits work & $-.074(.077)$ & $-.090(.078)$ & $-.044(.070)$ & $-.052(.074)$ \\
\hline \multicolumn{5}{|l|}{ SPOUSE PLANNING HORIZON } \\
\hline Next year & $-.092(.095)$ & $-.099(.097)$ & $.040(.099)$ & $.039(.101)$ \\
\hline Next few years & $-.086(.077)$ & $-.081(.078)$ & $.030(.078)$ & $.034(.079)$ \\
\hline Next $5-10$ years & $-.116(.082)$ & $-.112(.083)$ & $-.019(.081)$ & $.005(.084)$ \\
\hline Longer than 10 years & $.081(.107)$ & $.113(.110)$ & $.195(.102)$ & $.259^{* \star}(.115)$ \\
\hline Planning horizon missing & $.042(.201)$ & $.029(.208)$ & $.089(.175)$ & $.109(.178)$ \\
\hline \multicolumn{5}{|l|}{ HOUSEHOLD CHARACTERISTICS } \\
\hline Number of children & $-.016(.013)$ & $-.018(.013)$ & $.001(.012)$ & $.004(.013)$ \\
\hline Lump sum income (in $\$ 1,000$ ) & $.005^{\star \star}(.002)$ & $.005^{\star \star}(.002)$ & $.004^{\star *}(.002)$ & $.005^{\star *}(.002)$ \\
\hline $\begin{array}{l}\text { P-value of Wald test of } \\
\text { exogeneity }\end{array}$ & & .3491 & & .1950 \\
\hline Proportion retired & & 2932 & & .4411 \\
\hline No. of observations & & 3858 & & 3108 \\
\hline
\end{tabular}

NOTE: Standard errors in parentheses.

a. Nine observations in the female equation are dropped because age dummies perfectly predict outcomes.

* Statistically significant at the .10 level. ${ }^{* *}$ Statistically significant at the .05 level. 


\section{Table 3. Wealth regression results, single households}

Dependent variable: household wealth (in \$1000s)

(2)

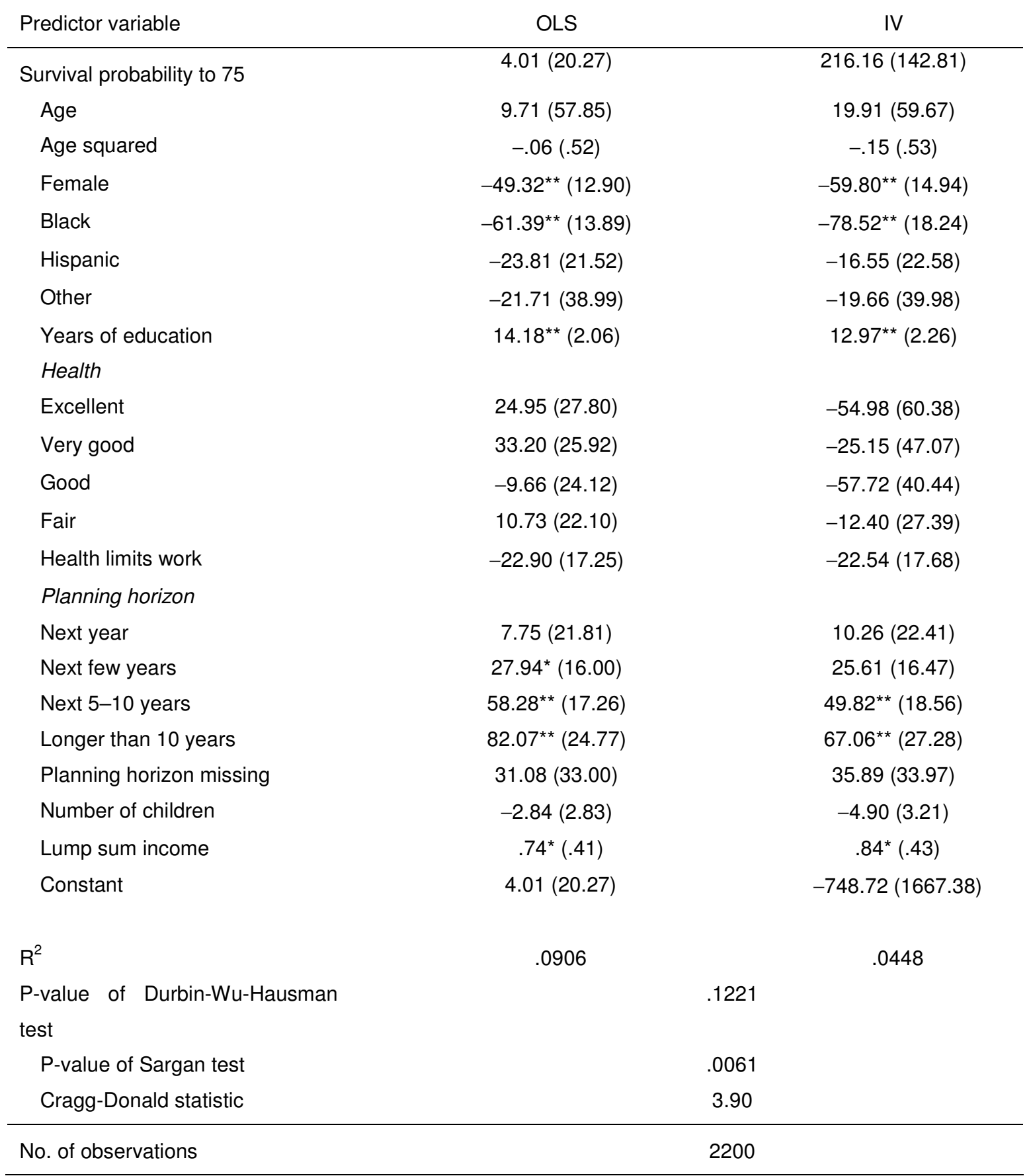

NOTE: Standard errors in parentheses.

* Statistically significant at the .10 level. ${ }^{* *}$ Statistically significant at the .05 level. 


\section{Table 4. Wealth regression results, couple households}

Dependent variable: household wealth (in $\$ 1,000$ s)

(1)

(2)

\begin{tabular}{|c|c|c|}
\hline Predictor variable & OLS & IV \\
\hline Husband's survival probability to 75 & $18.70(25.95)$ & $276.32^{*}(152.73)$ \\
\hline Wife's survival probability to 75 & $11.23(27.46)$ & $326.89^{\star *}(132.13)$ \\
\hline \multicolumn{3}{|l|}{ HUSBAND'S CHARACTERISTICS } \\
\hline Age & $58.88^{*}(34.09)$ & $55.69(35.23)$ \\
\hline Age squared & $-.47(.29)$ & $-.46(.30)$ \\
\hline Black & $-109.30(73.43)$ & $-128.56^{*}(76.36)$ \\
\hline Hispanic & $-117.63^{* *}(54.78)$ & $-109.59^{*}(56.70)$ \\
\hline Other & $58.46(60.19)$ & $-83.79(62.83)$ \\
\hline Years of education & $11.99^{\star \star}(2.72)$ & $10.80^{* *}(2.85)$ \\
\hline \multicolumn{3}{|l|}{ HUSBAND'S HEALTH } \\
\hline Excellent & $100.14^{\star \star}(37.07)$ & $-11.69(65.69)$ \\
\hline Very good & $33.93(35.41)$ & $-57.48(56.01)$ \\
\hline Good & $5.14(33.71)$ & $-66.52(47.38)$ \\
\hline Fair & $8.30(34.14)$ & $-30.62(38.33)$ \\
\hline Health limits work & $-31.71(20.82)$ & $-25.44(22.51)$ \\
\hline \multicolumn{3}{|l|}{ HUSBAND'S PLANNING HORIZON } \\
\hline Next year & $-14.53(29.12)$ & $-3.11(30.38)$ \\
\hline Next few years & $.15(22.48)$ & $-.61(23.24)$ \\
\hline Next $5-10$ years & $12.79(22.98)$ & $5.89(23.86)$ \\
\hline Longer than 10 years & $55.78^{*}(30.16)$ & 22.79 (33.97) \\
\hline Planning horizon missing & $63.73(53.13)$ & $60.10(54.96)$ \\
\hline \multicolumn{3}{|l|}{ WIFE'S CHARACTERISTICS } \\
\hline Age & $11.32(12.41)$ & $17.28(12.98)$ \\
\hline Age squared & $-.06(.12)$ & $-.12(.13)$ \\
\hline Black & $13.23(75.24)$ & $-5.80(78.00)$ \\
\hline Hispanic & $130.59^{\star \star}(51.52)$ & $121.80^{* *}(53.88)$ \\
\hline Other & $16.52(53.76)$ & $15.12(55.58)$ \\
\hline Years of education & $15.38^{\star *}(3.38)$ & $11.96^{\star \star}(3.69)$ \\
\hline \multicolumn{3}{|l|}{ WIFE'S HEALTH } \\
\hline Excellent & $78.52^{*}(51.22)$ & $-32.25(61.87)$ \\
\hline Very good & $72.50 *(39.58)$ & $-15.29(54.77)$ \\
\hline Good & $11.96(38.06)$ & $-58.95(48.88)$ \\
\hline Fair & $13.38(38.64)$ & $-27.71(43.76)$ \\
\hline Health limits work & $-25.70(21.31)$ & $-27.00(22.24)$ \\
\hline \multicolumn{3}{|l|}{ WIFE'S PLANNING HORIZON } \\
\hline Next year & $-21.15(27.18)$ & $-8.05(28.44)$ \\
\hline
\end{tabular}




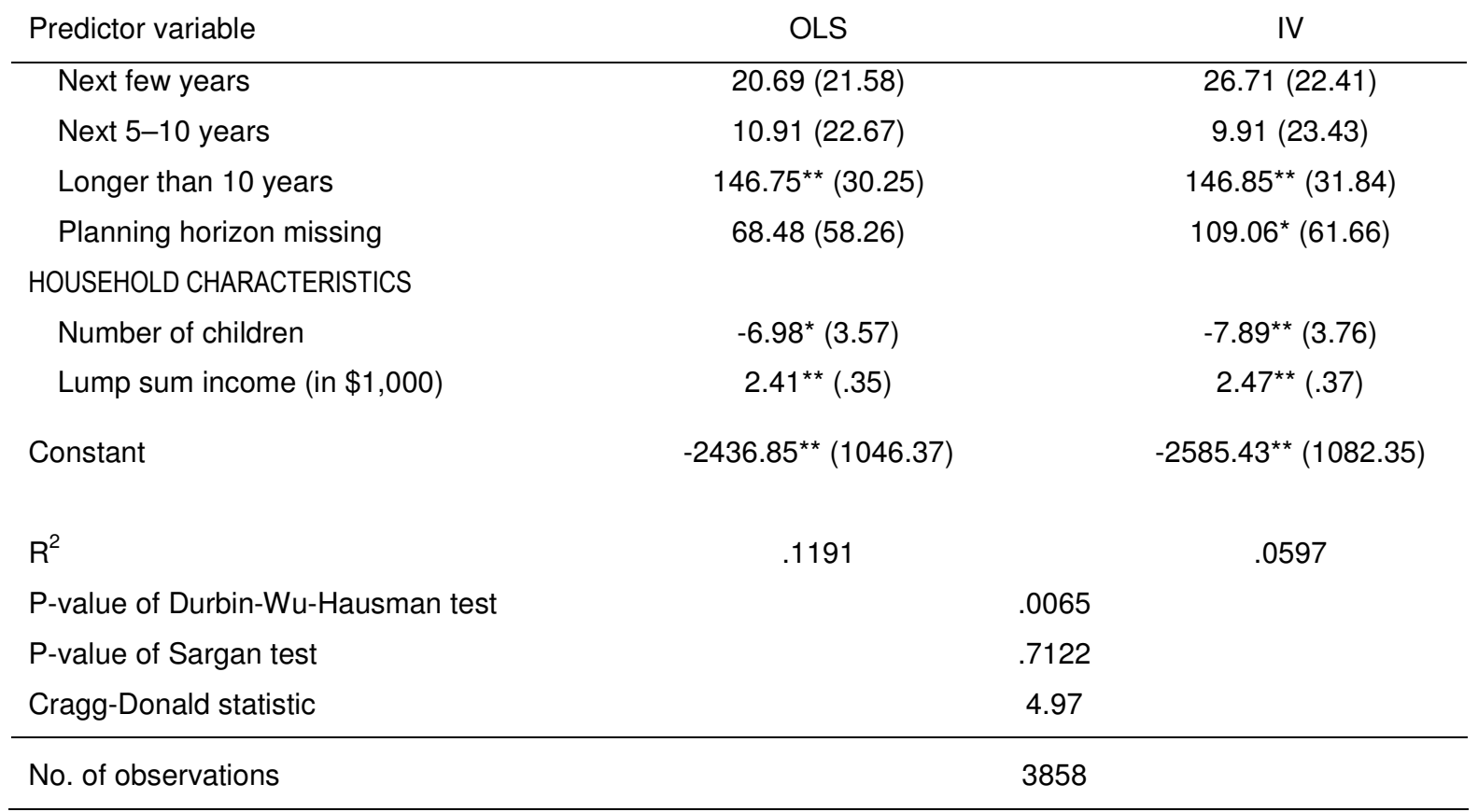

NOTE: Standard errors in parentheses

${ }^{*}$ Statistically significant at the .10 level. ${ }^{* *}$ Statistically significant at the .05 level. 
Table A1. Cumulative number and proportion of respondents deceased by wave 2 through 6

\begin{tabular}{lccc}
\hline Wave & All respondents & Females & Males \\
\hline 2 & $171(1.70)$ & $71(1.25)$ & $100(2.27)$ \\
3 & $379(3.76)$ & $149(2.63)$ & $230(5.22)$ \\
4 & $596(5.92)$ & $250(4.42)$ & $346(7.85)$ \\
5 & $867(8.61)$ & $358(6.32)$ & $509(11.54)$ \\
6 & $1,199(11.91)$ & $508(8.97)$ & $691(15.67)$ \\
\hline No. of observations & 10070 & 5661 & 4409 \\
\hline
\end{tabular}

NOTE: Mortality rates are in parentheses. 
Table A2. Marginal effects of subjective survival probability from probit estimation of the observed mortality, waves 2 through 6

(1)

$\frac{\text { Wave } 1 \text { controls }}{\text { Survival probability to } 75}$

Pseudo $\mathrm{R}^{2}$

Log pseudo likelihood

0.0334

$-837.50$
(3)

(2)

Wave $2 \quad$ Wave 3

Wave 4

$-.0518^{\star *}$

$-.0715^{\star *}$

(.0075)

(.0058)

0.0255

$-1573.70$

0.0214

$-2214.48$

10070
(4)

(5)

No. of observations

NOTE: Robust standard errors in parentheses.

${ }^{*}$ Statistically significant at the .10 level. ${ }^{* *}$ Statistically significant at the .05 level. 
Table A3 Marginal effects of subjective survival probability from probit estimation of the observed mortality, by selected variables, waves 2 through 6

(1)

Wave 1
Surviva
to 75
Age
Female

Black

Hispanic

Other

Years of education

Married

HEALTH

Excellent

Very good

Good

Fair

High blood pressure
(2)

(3)

(4)

Wave 2

Wave 3

Wave 4

Wave 5

Wave 6

$-.0043^{*}$

$-.0068$

$-.0098$

$-.0045$

$-.0089$

(.0024)

(.0042)

(.0060)

(.0077)

(.0097)

$.0004^{*}$

$.0008^{* *}$

$.0025^{\star *}$

$.0041^{\text {** }}$

$.0059^{* *}$

(.0002)

(.0003)

(.0005)

(.0006)

(.0007)

$-.0062^{\star \star}$

$-.0164^{\text {** }}$

$-.0199^{\star *}$

$-.0330^{* *}$

$-.0477^{\text {** }}$

(.0018)

(.0032)

(.0042)

(.0052)

(.0065)

$$
.0045^{*}
$$

$.0121^{\text {** }}$

$.0179^{* *}$

$.0137^{\star *}$

$.0142^{*}$

(.0028)

(.0046)

(.0061)

(.0070)

(.0084)

$$
.0002
$$

$-.0040$

$-.0039$

$-.0161^{*}$

$-.0241^{* *}$

$(.0031)$

(.0047)

(.0071)

(.0078)

(.0094)

$$
-.0017
$$

.0143

.0116

.0103

$-.0018$

$(.0046)$

(.0121)

$(.0148)$

(.0169)

(.0209)

$-.0001$

$-.0002$

.0004

$-.0004$

$-.0011$

(.0003)

(.0005)

(.0007)

(.0008)

(.0010)

$-.0032^{*} \quad-.0077^{\star *}$

$-.0058$

$-.0104^{*}$

$-.0205^{\text {** }}$

$(.0021)$

(.0035)

(.0045)

(.0057)

(.0072)

$-.0083^{\star *} \quad-.0190^{\star *}$

$-.0331^{* *}$

$-.0492^{* *}$

$-.0723^{\star \star}$

(.0053)

(.0066)

(.0084)

$$
\text { (.0037) }
$$

$-.0230^{* *}$

$-.0479^{* *}$

$-.0703^{\star \star}$

$(.0055)$

(.0068)

(.0086)

$\begin{array}{ll}(.0020) & (.0037)\end{array}$

$-.0290^{\star *}$

$-.0396^{\star *}$

$-.0574^{\star *}$

$(.0049)$

(.0063)

(.0082)

$(.0018) \quad(.0033)$

$-.0150^{* *}$

$-.0184^{* *}$

$-.0272^{\star *}$

(.0015)

(.0030)

(.0046)

(.0062)

(.0082)

$.0122^{\star *}$

$.0144^{* *}$

$.0270^{* *}$

$.0344^{* *}$ 


\begin{tabular}{|c|c|c|c|c|c|}
\hline \multirow[b]{2}{*}{ Wave 1 controls } & (1) & (2) & (3) & (4) & (5) \\
\hline & Wave 2 & Wave 3 & Wave 4 & Wave 5 & Wave 6 \\
\hline & $(.0019)$ & $(.0033)$ & $(.0043)$ & $(.0054)$ & $(.0066)$ \\
\hline \multirow[t]{2}{*}{ Diabetes } & $.0068^{* *}$ & $.0328^{\star \star}$ & $.0620^{\star \star}$ & $.0780^{\star \star}$ & $.1039^{\star \star}$ \\
\hline & $(.0035)$ & $(.0072)$ & $(.0099)$ & $(.0115)$ & $(.0135)$ \\
\hline \multirow[t]{2}{*}{ Cancer } & $.0418^{* *}$ & $.0632^{* *}$ & $.0783^{\star *}$ & $.1138^{\star \star}$ & $.1153^{\star *}$ \\
\hline & (.0092) & $(.0125)$ & $(.0144)$ & $(.0173)$ & $(.0186)$ \\
\hline \multirow[t]{2}{*}{ Lung disease } & $.0070^{\star *}$ & $.0225^{\star \star}$ & $.0361^{* *}$ & $.0521^{* \star}$ & $.0783^{\star \star}$ \\
\hline & $(.0042)$ & $(.0076)$ & (.0102) & $(.0125)$ & $(.0157)$ \\
\hline \multirow{2}{*}{$\begin{array}{l}\text { Ever had heart } \\
\text { attack }\end{array}$} & $.0090^{\star *}$ & $.0204^{\star *}$ & $.0300^{* *}$ & $.0483^{\star *}$ & $.0511^{* *}$ \\
\hline & $(.0034)$ & $(.0055)$ & $(.0072)$ & $(.0090)$ & $(.0105)$ \\
\hline \multirow[t]{2}{*}{ Stroke } & $.0113^{\star *}$ & $.0182^{\star \star}$ & $.0270^{\star \star}$ & $.0546^{\star \star}$ & $.1019^{\star \star}$ \\
\hline & $(.0067)$ & $(.0101)$ & $(.0135)$ & $(.0187)$ & $(.0246)$ \\
\hline \multirow[t]{2}{*}{ Arthritis } & -.0016 & .0011 & -.0015 & -.0077 & $-.0138^{* *}$ \\
\hline & $(.0016)$ & $(.0028)$ & $(.0038)$ & $(.0047)$ & $(.0059)$ \\
\hline \multirow[t]{2}{*}{ BMI } & -.0000 & $-.0009^{\star *}$ & $-.0011^{\star *}$ & $-.0015^{\star \star}$ & $-.0015^{\star *}$ \\
\hline & $(.0001)$ & $(.0003)$ & $(.0004)$ & (.0005) & $(.0006)$ \\
\hline \multirow[t]{2}{*}{ Smoker } & $.0083^{\star \star}$ & $.0236^{\star \star}$ & $.0500^{\star *}$ & $.0707^{\star \star}$ & $.1040^{\star *}$ \\
\hline & $(.0030)$ & $(.0052)$ & $(.0072)$ & $(.0087)$ & (.0102) \\
\hline \multirow[t]{2}{*}{ Former smoker } & $.0047^{\star \star}$ & $.0101^{\star \star}$ & $.0200^{\star *}$ & $.0317^{\star \star}$ & $.0416^{\star \star}$ \\
\hline & (.0022) & $(.0038)$ & (.0053) & $(.0064)$ & (.0078) \\
\hline Pseudo $R^{2}$ & 0.1843 & 0.1805 & 0.1716 & 0.1896 & 0.1882 \\
\hline $\begin{array}{r}\text { Log pseudo } \\
\text { likelihood }\end{array}$ & -706.82 & -1323.29 & -1874.67 & -2394.49 & -2984.37 \\
\hline No. of observations & \multicolumn{5}{|c|}{10070} \\
\hline
\end{tabular}

NOTES: Robust standard errors in parentheses. The reported regressions also include income and its square, wealth and its square.

${ }^{*}$ Statistically significant at the .10 level. ${ }^{* *}$ Statistically significant at the .05 level. 
Table A4. First-stage regression results in IV probit estimation of observed mortality: linear probability model of survival to age 75

\begin{tabular}{|c|c|c|}
\hline Predictor variable & Coefficient & Standard error \\
\hline Age & $.004^{* *}$ & .001 \\
\hline Female & $.036^{\star *}$ & .006 \\
\hline Black & $.069^{* *}$ & .009 \\
\hline Hispanic & $-.040^{\star *}$ & .012 \\
\hline Other & .010 & .020 \\
\hline Years of education & $.005^{\star *}$ & .001 \\
\hline Married & -.0001 & .007 \\
\hline Health: excellent & $.343^{* *}$ & .016 \\
\hline Health: very good & $.266^{* *}$ & .015 \\
\hline Health: good & $.213^{* *}$ & .015 \\
\hline Health: fair & $.114^{\star *}$ & .015 \\
\hline High blood pressure & $-.012^{*}$ & .006 \\
\hline Diabetes & -.013 & .011 \\
\hline Cancer & $-.028^{* *}$ & .013 \\
\hline Lung disease & $-.032^{* \star}$ & .014 \\
\hline Ever had heart attack & $-.040^{* *}$ & .010 \\
\hline Stroke & .014 & .021 \\
\hline Arthritis & .003 & .006 \\
\hline BMI & -.0001 & .001 \\
\hline Smoker & $-.027^{\star \star}$ & .007 \\
\hline Former smoker & .007 & .006 \\
\hline \multicolumn{3}{|l|}{ Parent alive } \\
\hline Mother's age $<75$ & $.088^{* *}$ & .012 \\
\hline Father's age $<75$ & $.051^{* *}$ & .017 \\
\hline Mother's age $75-85$ & $.075^{\star \star}$ & .009 \\
\hline Father's age $75-85$ & $.072^{\star *}$ & .009 \\
\hline Mother's age $>85$ & $.095^{\star *}$ & .013 \\
\hline Father's age $>85$ & $.080^{* *}$ & .015 \\
\hline \multicolumn{3}{|l|}{ Parent deceased } \\
\hline Mother's age of death $<50$ & $.040^{* *}$ & .014 \\
\hline Father's age of death $<50$ & $.037^{* *}$ & .011 \\
\hline Mother's age of death $66-75$ & $.023^{\star *}$ & .011 \\
\hline Father's age of death $66-75$ & $.027^{* *}$ & .008 \\
\hline Mother's age of death $>75$ & $.057^{\star \star}$ & .010 \\
\hline Father's age of death $>75$ & $.077^{\star *}$ & .008 \\
\hline
\end{tabular}




\begin{tabular}{ll} 
Predictor variable & Coefficient \\
\hline $\mathrm{R}^{2}$ & \\
\hline
\end{tabular}

No. of observations

10070

NOTE: The reported regressions also include income and its square, wealth and its square.

${ }^{*}$ Statistically significant at the .10 level. ${ }^{* *}$ Statistically significant at the .05 level. 
Table A5. Marginal effects of instrumented subjective survival probability from IV probit estimation of the observed mortality, waves 2 through 6

\begin{tabular}{lccccc} 
Wave 1 controls & Wave 2 & Wave 3 & Wave 4 & Wave 5 & Wave 6 \\
\hline $\begin{array}{l}\text { Survival probability } \\
\text { to } 75\end{array}$ & $-.0584^{\star *}$ & $-.1052^{\star *}$ & $-.2050^{\star *}$ & $-.2997^{\star *}$ & $-.4464^{\star *}$ \\
& $(.0304)$ & $(.0411)$ & $(.0559)$ & $(.0636)$ & $(.0715)$ \\
$\begin{array}{l}\text { Log pseudo } \\
\text { likelihood }\end{array}$ & -2691.84 & -3427.70 & -4065.28 & -4746.63 & -5447.14 \\
\hline No. of observations & & 10070 & \\
\hline
\end{tabular}

NOTE: Robust standard errors in parentheses.

${ }^{*}$ Statistically significant at the .10 level. ${ }^{* *}$ Statistically significant at the .05 level. 
Table A6. Marginal effects of instrumented subjective survival probability from IV probit estimation of the observed mortality, by selected variables, waves 2 through 6

(1)

\begin{tabular}{|c|c|c|c|c|c|}
\hline Wave 1 controls & Wave 2 & Wave 3 & Wave 4 & Wave 5 & Wave 6 \\
\hline \multirow{2}{*}{$\begin{array}{l}\text { Survival probability } \\
\text { to } 75\end{array}$} & -.0057 & .0037 & -.0257 & -.0436 & $-.1271^{*}$ \\
\hline & $(.0180)$ & $(.0311)$ & (.0433) & (.0525) & $(.0681)$ \\
\hline \multirow[t]{2}{*}{ Age } & $.0004^{*}$ & $.0008^{\star \star}$ & $.0026^{\star *}$ & $.0042^{* *}$ & $.0065^{\star \star}$ \\
\hline & $(.0002)$ & $(.0004)$ & $(.0005)$ & $(.0006)$ & $(.0008)$ \\
\hline \multirow[t]{2}{*}{ Female } & $-.0061^{* *}$ & $-.0169^{* *}$ & $-.0194^{\star \star}$ & $-.0318^{\star *}$ & $-.0442^{* *}$ \\
\hline & $(.0019)$ & $(.0037)$ & $(.0044)$ & $(.0054)$ & $(.0068)$ \\
\hline \multirow[t]{2}{*}{ Black } & .0046 & $.0112^{* *}$ & $.0193^{\star *}$ & $.0169^{\star *}$ & $.0235^{* *}$ \\
\hline & $(.0033)$ & $(.0052)$ & $(.0075)$ & $(.0085)$ & $(.0104)$ \\
\hline \multirow[t]{2}{*}{ Hispanic } & .0002 & -.0037 & -.0044 & $-.0173^{\star *}$ & $-.0278^{\star *}$ \\
\hline & $(.0032)$ & (.0049) & $(.0072)$ & $(.0077)$ & $(.0098)$ \\
\hline \multirow[t]{2}{*}{ Other } & -.0016 & .0142 & .0118 & .0108 & -.0010 \\
\hline & $(.0046)$ & (.0122) & $(.0149)$ & $(.0170)$ & $(.0214)$ \\
\hline \multirow[t]{2}{*}{ Years of education } & -.0001 & -.0003 & .0004 & -.0002 & -.0004 \\
\hline & $(.0003)$ & $(.0005)$ & $(.0007)$ & $(.0009)$ & $(.0011)$ \\
\hline \multirow[t]{2}{*}{ Married } & -.0032 & $-.0077^{\star \star}$ & -.0059 & $-.0105^{\star}$ & $-.0210^{\star *}$ \\
\hline & $(.0021)$ & $(.0035)$ & $(.0045)$ & $(.0058)$ & $(.0074)$ \\
\hline \multirow[t]{2}{*}{ Health: Excellent } & $-.0080^{\star *}$ & $-.0213^{\star \star}$ & $-.0297^{\star *}$ & $-.0409^{\star *}$ & $-.0453^{* *}$ \\
\hline & $(.0039)$ & $(.0077)$ & $(.0108)$ & $(.0136)$ & $(.0196)$ \\
\hline \multirow[t]{2}{*}{ Health: Very good } & $-.0084^{\star *}$ & $-.0222^{* *}$ & $-.0265^{\star \star}$ & $-.0405^{\star \star}$ & $-.0471^{* *}$ \\
\hline & $(.0037)$ & $(.0073)$ & $(.0100)$ & $(.0119)$ & $(.0165)$ \\
\hline \multirow[t]{2}{*}{ Health: Good } & $-.0086^{\star \star}$ & $-.0211^{\star *}$ & $-.0266^{\star \star}$ & $-.0333^{\star *}$ & $-.0380^{\star *}$ \\
\hline & $(.0031)$ & $(.0062)$ & $(.0082)$ & $(.0105)$ & $(.0145)$ \\
\hline \multirow[t]{2}{*}{ Health: Fair } & $-.0045^{\star \star}$ & $-.0103^{\star \star}$ & $-.0137^{\star *}$ & $-.0149^{\star}$ & -.0164 \\
\hline & $(.0019)$ & $(.0041)$ & $(.0059)$ & $(.0080)$ & $(.0112)$ \\
\hline \multirow[t]{2}{*}{ High blood pressure } & $.0034^{*}$ & $.0124^{\star *}$ & $.0142^{\star *}$ & $.0265^{\star *}$ & $.0331^{* *}$ \\
\hline & $(.0019)$ & $(.0035)$ & $(.0043)$ & $(.0055)$ & $(.0067)$ \\
\hline \multirow[t]{2}{*}{ Diabetes } & $.0068^{* *}$ & $.0332^{* *}$ & $.0616^{\star *}$ & $.0771^{* *}$ & $.1014^{* *}$ \\
\hline & $(.0035)$ & $(.0074)$ & $(.0099)$ & $(.0114)$ & $(.0134)$ \\
\hline \multirow[t]{2}{*}{ Cancer } & $.0416^{\star \star}$ & $.0644^{\star *}$ & $.0773^{\star *}$ & $.1114^{\star *}$ & $.1096^{\star \star}$ \\
\hline & $(.0096)$ & $(.0134)$ & $(.0145)$ & $(.0173)$ & $(.0184)$ \\
\hline \multirow[t]{2}{*}{ Lung disease } & .0069 & $.0233^{* *}$ & $.0351^{* *}$ & $.0499^{* *}$ & $.0721^{* *}$ \\
\hline & $(.0043)$ & $(.0081)$ & $(.0103)$ & $(.0126)$ & $(.0156)$ \\
\hline \multirow{2}{*}{$\begin{array}{l}\text { Ever had heart } \\
\text { attack }\end{array}$} & $.0089^{\star *}$ & $.0212^{* *}$ & $.0291^{\star *}$ & $.0461^{* *}$ & $.0453^{* *}$ \\
\hline & $(.0036)$ & $(.0063)$ & $(.0075)$ & $(.0094)$ & $(.0108)$ \\
\hline Stroke & $.0113^{*}$ & $.0181^{*}$ & $.0273^{\star \star}$ & $.0554^{\star *}$ & $.1044^{\star \star}$ \\
\hline
\end{tabular}




\begin{tabular}{|c|c|c|c|c|c|}
\hline & (1) & (2) & (3) & (4) & (5) \\
\hline \multirow[t]{2}{*}{ Wave 1 controls } & Wave 2 & Wave 3 & Wave 4 & Wave 5 & Wave 6 \\
\hline & $(.0067)$ & $(.0102)$ & $(.0135)$ & $(.0189)$ & $(.0249)$ \\
\hline \multirow[t]{2}{*}{ Arthritis } & -.0016 & .0010 & -.0014 & -.0076 & $-.0136^{* *}$ \\
\hline & $(.0016)$ & $(.0028)$ & $(.0039)$ & $(.0048)$ & $(.0061)$ \\
\hline \multirow[t]{2}{*}{ BMI } & -.00002 & $-.0009^{* *}$ & $-.0011^{* *}$ & $-.0015^{\star *}$ & $-.0016^{\star *}$ \\
\hline & $(.0001)$ & $(.0003)$ & $(.0004)$ & $(.0005)$ & $(.0006)$ \\
\hline \multirow[t]{2}{*}{ Smoker } & $.0083^{\star *}$ & $.0241^{* *}$ & $.0493^{\star *}$ & $.0693^{* *}$ & $.1001^{* *}$ \\
\hline & $(.0031)$ & $(.0057)$ & $(.0074)$ & (.0088) & $(.0104)$ \\
\hline \multirow[t]{2}{*}{ Former smoker } & $.0047^{* *}$ & $.0100^{\star *}$ & $.0202^{\star *}$ & $.0321^{* *}$ & $.0429^{* *}$ \\
\hline & $(.0022)$ & $(.0038)$ & $(.0053)$ & (.0065) & $(.0080)$ \\
\hline $\begin{array}{l}\text { Log pseudo } \\
\text { likelihood }\end{array}$ & -1715.35 & -2331.76 & -2883.13 & -3402.73 & -3991.21 \\
\hline
\end{tabular}

No. of observations

10070

NOTES: Robust standard errors in parentheses. The reported regressions also include income and its square, wealth and its square.

${ }^{*}$ Statistically significant at the .10 level. ${ }^{* *}$ Statistically significant at the .05 level. 
Figure 1. Proportion retired by age, whole sample

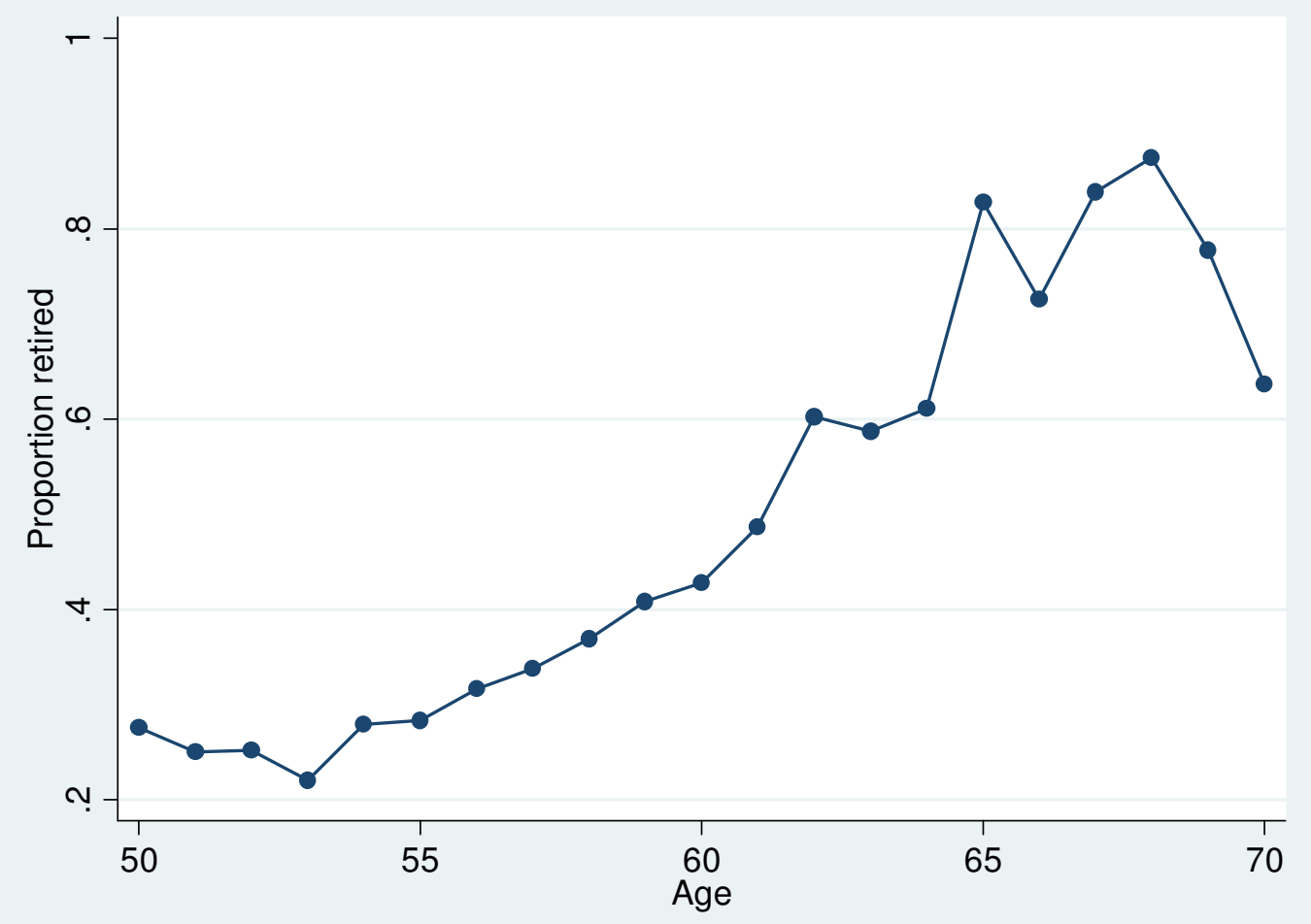


Figure 2. Kernel density graph of wealth

Panel A. Singles

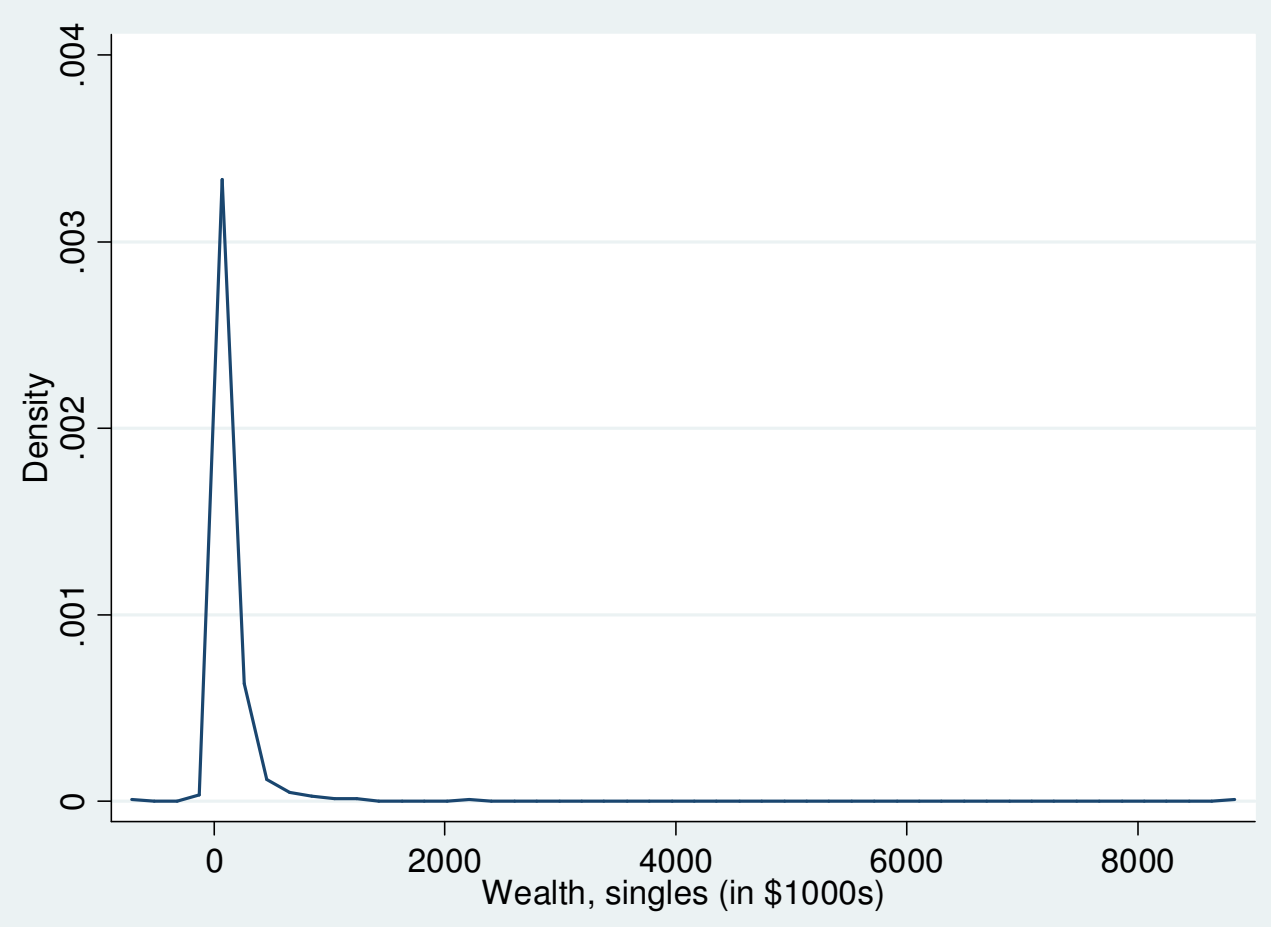

Panel B. Couples

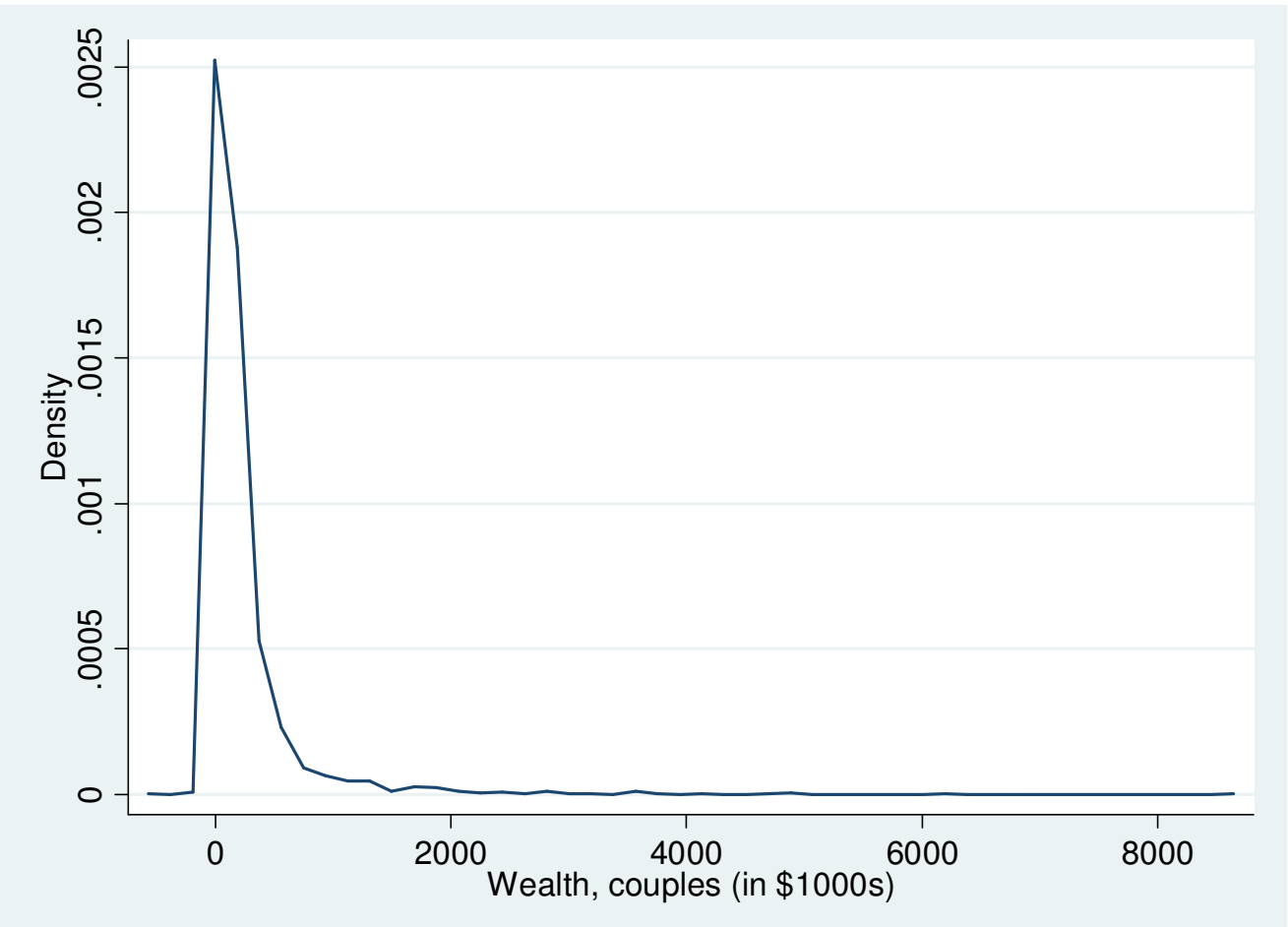


Figure A1. Histogram of the reported survival probability to age 75

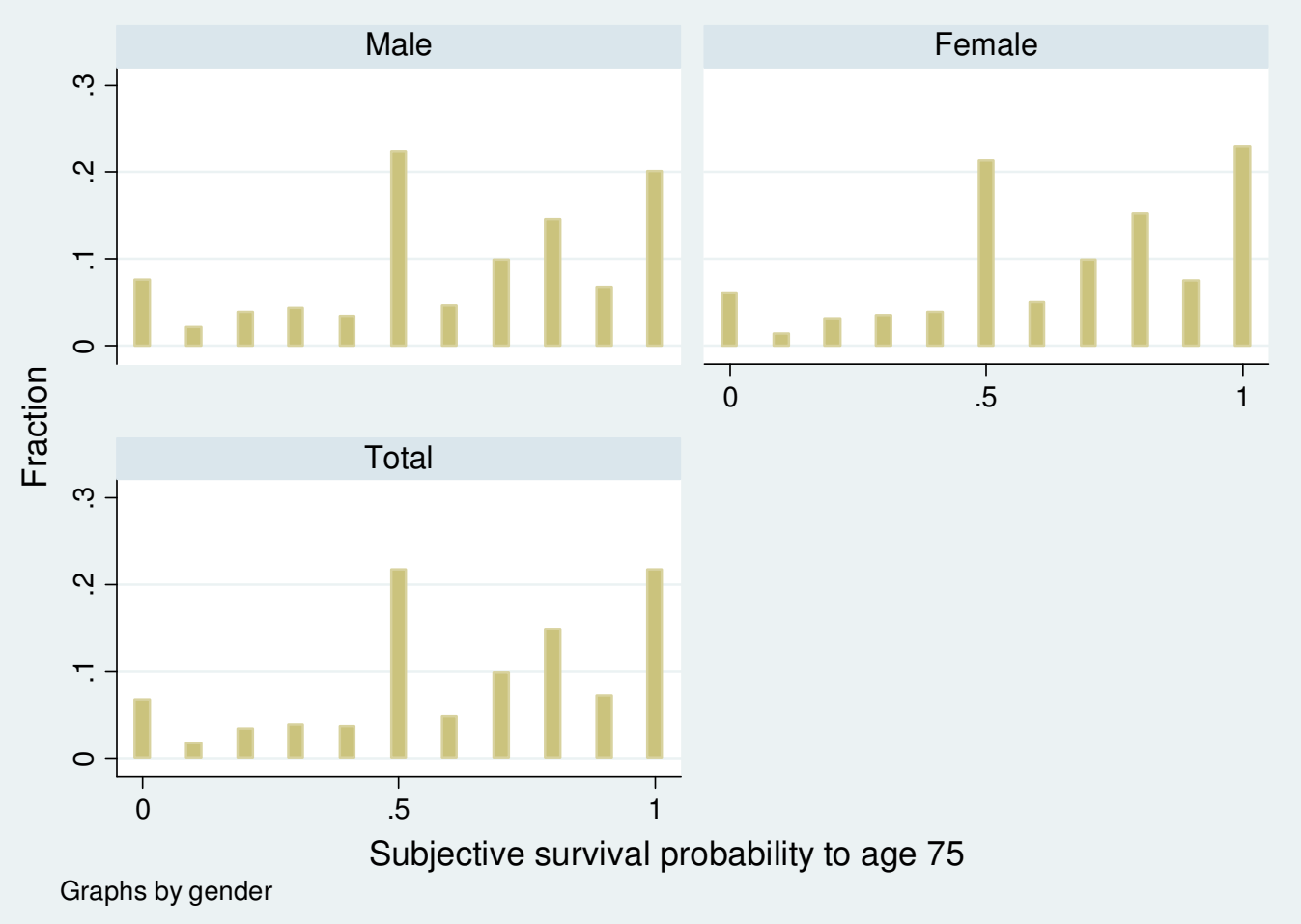


Figure A2. Distribution of the instrumented survival probability to age 75 in the estimation of observed mortality

Panel A. Histogram

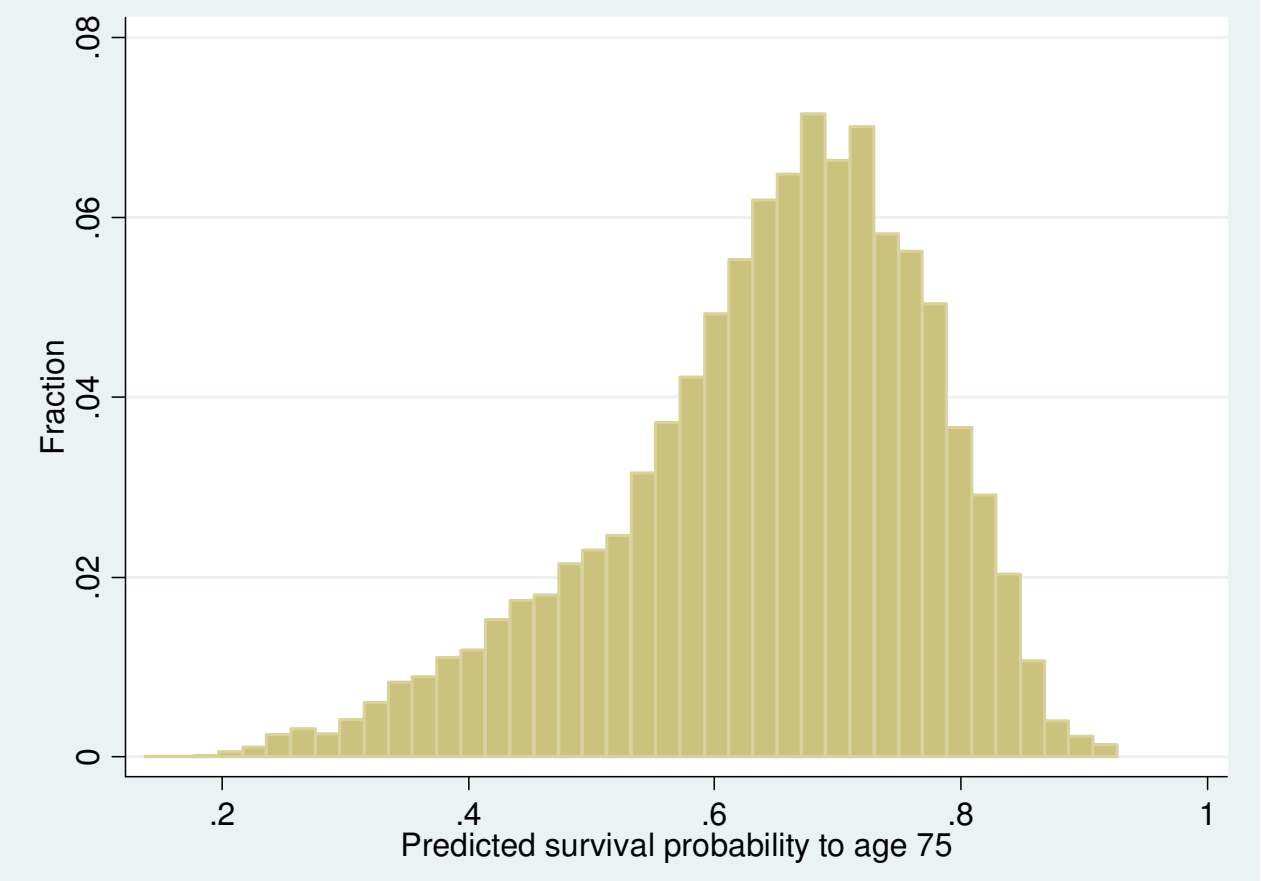

Panel B. Kernel density

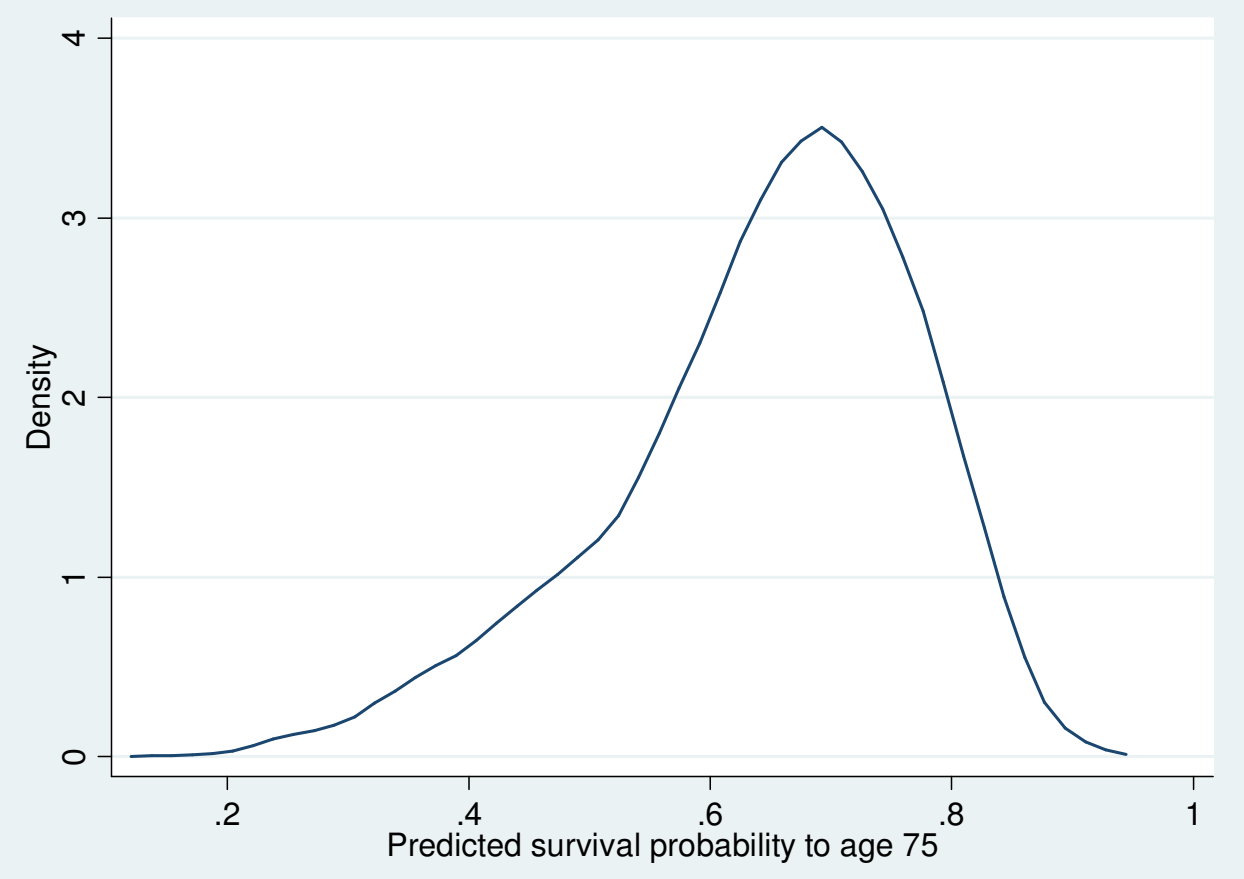




\section{References}

Bassett, William F. and Robin L. Lumsdaine (2001), 'Probability limits: Are subjective assessments adequately accurate?', Journal of Human Resources, 36 (2), 327-63.

Blondal, Sveinbjorn and Stefano Scarpetta (1997), 'Early retirement in OECD countries: The role of social security systems', OECD Economic Studies, 29 (1997/II), 7-54.

Bloom, David E., David Canning and Bryan Graham (2003), 'Longevity and life-cycle savings', Scandinavian Journal of Economics, 105, 319-38.

Bloom, David E., David Canning and Michael Moore (2004), 'Health, Longevity, and Optimal Retirement', NBER Working Paper 10919, National Bureau of Economic Research, Cambridge, MA, August.

Bloom, David E., David Canning, Rick Mansfield and Michael Moore (2007), 'Demographic change, social security systems, and savings', Journal of Monetary Economics, in press.

Bloom, David E., David Canning, Michael Moore and Younghwan Song (2006), 'The Effect of Subjective Survival Probabilities on Retirement and Saving', manuscript, Harvard School of Public Health, Boston, Massachusetts, July.

Bongaarts, John and Griffith Feeney (2003), 'Estimating mean lifetimes', Proceedings of the National Academy of Sciences, 100, 13127-33.

Boucekkine, Raouf, David de la Croix and Omar Licandro (2002), 'Vintage human capital, demographic trends, and endogenous growth', Journal of Economic Theory, 104, 34075.

Costa, Dora L. (2002), 'Changing chronic disease rates and long-term declines in functional limitation among older men', Demography, 39, 119-37.

Crimmins, Eileen M. (2004), 'Trends in the health of the elderly', Annual Review of Public Health, 25, 79-98. 
Crimmins, Eileen M., Yasuhiko Saito and Dominique Ingegneri (1997), 'Trends in disability-free life expectancy in the United States, 1970-90', Population Development Review, 23, 555-72.

Deaton, A. (1992), Understanding Consumption, Oxford: Oxford University Press.

Deaton, Angus and Christina H. Paxson (1994), 'Savings, growth, and aging in Taiwan', in David Wise (ed.), Studies in the Economics of Aging, Chicago: National Bureau of Economic Research and University of Chicago Press.

—, (1997), 'The effects of economic and population growth on national savings and inequality', Demography, 34, 97-114.

- (2000), 'Growth, demographic structure, and national savings in Taiwan', Population and Development Review, 26 (supplement), 141-73.

Fries, James F. (1980), 'Aging, natural death, and the compression of morbidity', New England Journal of Medicine, 303, 130-35.

— , (1989), 'The compression of morbidity: Near or far?' Milbank Quarterly, 67, 208-32.

Gruber, Jonathan and David Wise (1998), 'Social security and retirement: An international comparison', American Economic Review, 88, 158-63.

Gustman, Alan L. and Thomas L. Steinmeier (2000), 'Retirement outcomes in the Health and Retirement Study', Social Security Bulletin, 63 (4), 57-71.

Hamermesh, Daniel S. (1985), 'Expectations, life expectancy, and economic behavior', Quarterly Journal of Economics, 100 (2), 389-408.

Hamermesh, Daniel S. and Frances W. Hamermesh (1983), 'Does perception of life expectancy reflect health knowledge?' American Journal of Public Health, 73 (8), 911-14.

Hurd, Michael D., Daniel McFadden and Li Gan (1998), 'Subjective survival curves and life cycle behavior', in David Wise (ed.), Inquiries in the Economics of Aging, Chicago: University of Chicago Press. 
Hurd, Michael D. and Kathleen McGarry (1995), 'Evaluation of the subjective probabilities of survival', Journal of Human Resources, 30 (Supplement), S268-92.

Hurd, Michael D. and Kathleen McGarry (2002), 'The predictive validity of subjective probabilities of survival', Economic Journal, 112 (October), 966-85.

Hurd, Michael D., James P. Smith and Julie M. Zissimopoulos (2004), 'The effects of subjective survival on retirement and Social Security claiming', Journal of Applied Econometrics, $19,761-75$.

Kalemli-Ozcan, Sebnem and David N. Weil (2005), 'Mortality change, the uncertainty effect, and retirement', manuscript, Brown University, Providence, RI, August.

Kulish, Mariano, Kathryn Smith and Christopher Kent (2006), 'Ageing, retirement, and savings: A general equilibrium analysis', research discussion paper, Economic Research Department, Reserve Bank of Australia, Sydney, June.

Lee, Ronald D., Andrew Mason and Tim Miller (1998), 'Saving, Wealth, and Population', unpublished manuscript, University of California at Berkeley.

- (2000), 'Life cycle saving and the demographic transition: The case of Taiwan', Population and Development Review, 26 (Supplement), 194-219.

Li, Nan and Ronald Lee (2005), 'Coherent mortality forecasts for a group of populations: An extension of the Lee-Carter method', Demography, 42 (3), 575-94.

Mor, Vincent (2005), 'The compression of morbidity hypothesis: A review of research and prospects for the future', Journal of the American Geriatric Society, 53, S308-09.

Siegel, Michele, Elizabeth H. Bradley and Stanislav V. Kasl (2003), 'Self-rated life expectancy as a predictor of mortality: Evidence from the HRS and AHEAD surveys', Gerontology, 49, 265-71.

Stock, James H. and Motohiro Yogo (2002), 'Testing for weak instruments in Linear IV Regression', NBER Technical Working Paper 284, National Bureau of Economic Research, Cambridge, MA, November. 
Tsai I-J, C.Y.C. Chu and Cyrus F. Chung (2000), 'Demographic transition and household saving in Taiwan', Population and Development Review, 26 (supplement), 174-93. 